\title{
Heterotic Responses for Yield and its Components in Faba Bean (Vicia Faba L.)
}

\author{
Kanhaiya Lal $^{1 *}$, C.B. Yadav ${ }^{1}$, Shiva Nath ${ }^{1}$ and D.K. Dwivedi ${ }^{2}$ \\ ${ }^{1}$ Department of Genetics and Plant Breeding, Narendra Deva University of Agriculture and \\ Technology, Kumarganj, Ayodhya, (U.P.) India \\ ${ }^{2}$ Department of Plant Molecular Biology and Genetic Engineering, Narendra Deva University \\ of Agriculture and Technology, Kumarganj, Ayodhya, (U.P.) India \\ *Corresponding author
}

\section{A B S T R A C T}

The present investigation was carried out during the year 2016-17 and 2017-18 at Narendra Deva University of Agriculture and Technology, Ayodhya with the objective to

\section{Keywords}

Faba bean,

Heterotic response,

Vicia faba, Yield

component traits

Article Info

Accepted:

07 May 2019

Available Online:

10 June 2019 estimate heterotic responses in yield component traits in 45 hybrid combinations developed by crossing 15 lines (females) with 3 testers (males). The experiment was laid out in randomized complete block design with three replications and observations were recorded on 5 randomly selected plants for 12 quantitative traits. Heterosis was estimated as per cent increase or decrease of $F_{1}$ value over better parent (BP) and two standard varieties $(\mathrm{SV})$ viz., HFB $1\left(\mathrm{SV}_{1}\right)$ and Vikrant $\left(\mathrm{SV}_{2}\right)$. Significant positive as well as negative heterosis was observed for days to 50 per cent flowering, days to maturity, plant height $(\mathrm{cm})$, number of branches per plant, number of pods per plant, pod length $(\mathrm{cm})$, number of seeds per pod, 100-seed weight (g), biological yield per plant $(\mathrm{g})$, harvest index $(\%)$, protein content $(\%)$ and grain yield per plant $(\mathrm{g})$. The estimates of heterobeltiosis and standard heterosis for twelve characters of forty five crosses have been presented and discussed in the present study. The most desirable crosses showing high mean performance along with high and significant heterobeltiosis and standard heterosis for grain yield per plant merit further testing and evaluation in adaptive trials to find out their feasibility for recommendation as hybrid cultivars of faba bean.

\section{Introduction}

Faba bean (fabaceae) is one of the oldest crops grown by man (Maalouf, 2011). It is one of the most efficient atmospheric nitrogen fixers contributing to soil nitrogen content improvement and an alternative good source of protein for humans in developing countries and for animals in industrialized countries
(Zeinab and Helal, 2014). The protein content in Faba bean ranges from 20 to 40 per cent depending upon the genotype and the environmental conditions. Despite the huge importance of Faba bean as a protein source for humans and animals in ensuring food and nutritional security in context of global population increase and global climate change, its full potential through hybrid 
breeding remains unexploited largely due to its unique pollination biology and yield instability (Bishnoi et al., 2015). Faba bean is an often cross pollinated crop. The range of cross pollination in this crop has been reported from 4 and 84 per cent. The rate of outcrossing depends on the genotype, environmental factors, row space and the number of pollinating insects, especially honeybees (Bishnoi et al., 2012).

The increased yield caused by heterozygosity due to outcrossing has been well documented in Faba bean. Cross pollination in faba bean has been associated with increased seed yields and accelerated growth. The heterotic effects in faba bean may range from significantly positive to significantly negative for different characters depending on the genetic makeup of the parents. Superiority of hybrids over the better parent and standard varieties for grain yield and its attributes are associated with the magnitude of heterotic effects in important yield contributing traits viz., number of branches per plant, number of pods per plant, number of seeds per pod and 100-seed weight (Bishnoi et al., 2012, Zeinab and Helal, 2014; Abdalla et al., 2015; Saad et al., 2015). Hence, estimate of heterosis, which is expressed as increase in vigour of the $F_{1}$ hybrids over the better parent and standard varieties in various yield component traits, provides important information for improving grain yield and other yield attributes in Faba bean. The present study was carried out with the objective to estimate heterosis in 12quantitative traits in 45crosses involving 18 genotypes of diverse origin.

\section{Materials and Methods}

This trial was carried out at the Students' Instructional Farm of the Narendra Deva University of Agriculture and Technology, Ayodhya (U. P.) India. The experimental material was based on a line $\mathrm{x}$ tester set of 45 hybrids $\left(\mathrm{F}_{1}\right.$ 's) developed by crossing 15 lines (females) viz., EC 243626, EC 329706, EC 301470, EC 454751, EC 263620, EC 5873, EC 10719, EC 329627, EC 25085, HB 10, HB 30, HB 50, IC 598958, IC 374731 and EC 10845 with 3 testers (males) viz., DFB 14-1, HB 09-15 and HB 09-16. The $45 \mathrm{~F}_{1}$ 's along with their parents including two checks, HFB 1 and Vikrant were evaluated in randomized complete block design with three replications during Rabi 2017-18. Each plot consisted of a single row of $3 \mathrm{~m}$ length with inter and intra row spacing of $30 \mathrm{~cm}$ and $10 \mathrm{~cm}$, respectively. The sowing was done on $26^{\text {th }}$ November, 2017. Recommended cultural practices were followed to raise a good crop.

For estimation of heterosis over better parent and standard varieties (HFB 1 and Vikrant),observations were recorded on 5 randomly selected plants for 12 characters viz., days to 50 per cent flowering, days to maturity, plant height $(\mathrm{cm})$, number of branches per plant, number of pods per plant, pod length $(\mathrm{cm})$, number of seeds per pod, biological yield per plant $(\mathrm{g})$, harvest index (\%), 100-seed weight (g), protein content (\%) and grain yield per plant $(\mathrm{g})$ and heterosis was computed as per cent increase or decrease of the mean values of crosses ( $F_{1}$ 's) over better parent (Heterobeltiosis) and standard varieties (Standard Heterosis) as follows:

1 .

Heterosis over better parent (Heterobel tiosis) $=\frac{\overline{\mathrm{F}}_{1}-\overline{\mathrm{BP}}}{\overline{\mathrm{BP}}} \times 100$

2.

Heterosis over standard variety (Standard heterosis) $=\frac{\overline{\mathrm{F}}_{1}-\overline{\mathrm{SV}}}{\overline{\mathrm{SV}}} \times 100$

Where,

$\frac{\mathrm{F}_{1}}{1}=$ Mean of $\mathrm{F}_{1}$
$\overline{\mathrm{BP}}=$ Mean of better - parent
$\overline{\mathrm{SV}}=$ Mean of standard variety or check vari ety 
The test of significance was applied to determine the significance of heterosis by using the following formula:

$$
\begin{aligned}
& \text { ' } \mathrm{t} \text { ' (Heterobel tiosis) }=\frac{\overline{\mathrm{F}}_{1}-\mathrm{BP}}{\mathrm{S.E} .} \\
& \text { ' } \mathrm{t} \text { ' (Standard heterosis) }=\frac{\overline{\mathrm{F}}_{1}-\overline{\mathrm{SV}}}{\text { S.E. }} \\
& \text { S.E. of heterosis over better parent and standard variety }=\sqrt{2 \mathrm{Me} / \mathrm{r}}
\end{aligned}
$$

Where,

$\mathrm{Me} \quad=\quad$ Mean error variance

$\mathrm{r} \quad=\quad$ Number of replications.

Thus, C.D. $=\mathrm{SE} \times$ 't' value at error d.f. and $5 \%$ or $1 \%$ probability level. Critical difference was used to test the significance of difference mean value of $F_{1}$ over better parent and standard variety which signified significance of the respective heterosis.

\section{Results and Discussion}

\section{Mean performance}

The mean performance of the 18 parental genotypes along with their $\mathrm{F}_{1}$ 's has been presented in Table 1. Among the parental genotypes the genotype HB 50 (65 days) was earliest to flower, while the genotypes EC 454751 and DFB 14-1 (72 days) were the latest to flower. Among hybrids, the cross EC 329706 x DFB 14-1 (65 days) was earliest to flower, while EC 25085 x HB 09-15, IC 598958 x DFB 14-1, IC 598958 x HB 09-15, EC 10845 x HB 09-16, HB 10 x DFB 14-1 and HB $10 \times$ HB 09-15 (72 days) were the latest one. Similarly, among parents, HB 50 (135 days) and EC 5873, EC 329627 and EC 454751 (142 days) were earliest and latest to mature, while the crosses EC $329706 \times$ DFB 14-1 (136 days) and IC 598958 x DFB 14-1 (143 days) were earliest and latest to mature with the mean number of days in parenthesis. The genotype HB $50 \quad(92.39 \mathrm{~cm})$ had maximum average plant height and EC $454751(81.44 \mathrm{~cm})$ had the minimum. Among the crosses, EC $454751 \times$ HB 09-16 (108.67 $\mathrm{cm})$ and EC $263620 \times$ DFB $14-1(71.78 \mathrm{~cm})$ had tallest and shortest plants, respectively. The genotypes EC 25085 (4.20) and IC 598958 (2.60) ranked first and last respectively, in number of branches per plant and the first and last ranking respective crosses were HB 30 x DFB 14-1(4.80) and EC 10719 x HB 09-16, EC 243626 x DFB 141 \& HB 30 x HB 09-16 (2.60). The parental genotype EC 25085 (15.67) had maximum number of pods per plant, while EC 329627 (9.20) had the minimum average for the same trait. Among the crosses for the same character EC $454751 \times$ HB 09-16 (20.93) and EC 598958 x DFB 14-1 (9.40) exhibited maximum and minimum average number of pods per plant, respectively. The character pod length displayed a range of variability with HB 09-15 (3.63 cm) to EC 10719 (6.63 $\mathrm{cm})$ at minimum and maximum limits among the parents, respectively, and IC $374731 \times \mathrm{HB}$ 09-16 (3.38 cm) to EC $263620 \times$ HB 09-16 $(6.68 \mathrm{~cm})$ among the crosses. Among parents, minimum and maximum number of seeds per pod were found in EC 25085 \&HB 09-15 (2.82) and EC 329627 (4.00), respectively. It varied from 2.82 (IC 598958 x DFB 14-1, IC 374731 x HB 09-16, EC 329706 x HB 09-16 and EC $454751 \times \mathrm{HB}$ 09-15) to 4.00 (EC $263620 \times$ HB 09-16 and IC $598958 \times$ DFB 14-1) among the crosses also. Biological yield per plant of parents varied from $22.93 \mathrm{~g}$ (HB 30) to $37.13 \mathrm{~g}$ (IC 598958), while in crosses it ranged from $22.53 \mathrm{~g}$ (IC $598958 \mathrm{x}$ DFB 14-1) to $44.00 \mathrm{~g}$ (EC $329706 \times \mathrm{HB}$ 09-16). Harvest index ranged from $28.75 \%$ (EC 5873) to $38.01 \%$ (HB 50) in parents and from $30.14 \%$ (EC 243626 x DFB 14-1) to $42.28 \%$ (HB 50 x HB 09-16) in crosses. Among parents, minimum and maximum 100-seed weight was recorded in HB 09-16 (22.97 g) and IC 
374731 (33.97 g), respectively. In crosses, it varied from $25.01 \mathrm{~g}$ (EC $329706 \mathrm{x} \mathrm{HB}$ 09-15) to $32.36 \mathrm{~g}$ (EC $329706 \times \mathrm{HB}$ 09-16). Among parents, minimum and maximum protein content was recorded in EC 329627 (19.17\%) and EC 329706 (26.91\%) respectively. In crosses, it varied from $19.54 \%$ (EC $5873 \times$ DFB 14-1) to $27.51 \%$ (IC $374731 \times$ HB 09 15). Among parents, minimum and maximum grain yield was recorded in HB 09-16 (8.03 g) and HB 50 (13.58 g) respectively. In crosses, it varied from $7.67 \mathrm{~g}$ (IC $598958 \times$ DFB 14-1) to $17.28 \mathrm{~g}$ (EC $243626 \times \mathrm{HB} 09-16)$.

\section{Heterotic responses}

Heterosis was estimated as per cent increase or decrease of $F_{1}$ value over better parent (BP) and two standard varieties viz., HFB 1 $\left(\mathrm{SV}_{1}\right)$ and Vikrant $\left(\mathrm{SV}_{2}\right)$. The estimates of heterobeltiosis and standard heterosis for twelve characters of forty five crosses presented in Table 2. For days to per cent flowering, the heterosis over better-parent (BP) ranged from -9.26 (EC $329706 \times$ DFB 14-1) to 3.86 per cent (HB $50 \times$ HB 09-16). The heterosis over standard variety $\mathrm{SV}_{1}$ (HFB 1) ranged from -6.67 (EC $329706 \times$ DFB 141) to 2.86 per cent (EC $25085 \times$ HB 09-15, HB 10 x DFB 14-1, HB 10 x HB 09-15, IC 598958 x DFB 14-1, IC 598958 HB 09-15, EC $10845 \times$ X HB 09-16) and over $\mathrm{SV}_{2}$ (Vikrant) ranged from -5.31 (EC $329706 \mathrm{x}$ DFB 14-1) to 4.35 per cent (EC $25085 \times \mathrm{HB}$ 09-15, HB 10 x DFB 14-1, HB 10 x HB 0915, IC 598958 x DFB 14-1, IC 598958 HB 09-15, EC 10845 x HB 09-16). The estimates of mean heterosis were $-1.68,-0.12$ and 1.33 per cent over $\mathrm{BP}, \mathrm{SV}_{1}$ and $\mathrm{SV}_{2}$, respectively. The negative heterosis is desirable in the trait days to 50 per cent flowering. The eighteen crosses exhibited negative and significant heterosis over $\mathrm{BP}$, eight crosses over $\mathrm{SV}_{1}$ and three crossesover $\mathrm{SV}_{2}$. The negative heterosis is also desirable in the trait days to maturity and means of heterosis for the trait were found $-0.87,-0.79$ and -0.56 per cent over BP, $\mathrm{SV}_{1}$ and $\mathrm{SV}_{2}$, respectively and it was varied from -3.76 (EC 329706 x DFB 14-1, HB 30 x DFB 14-1) to 2.40 per cent (HB 50 x HB 0916) over $B P$ whereas, it ranged from -3.31 (EC 329706 x DFB 14-1, HB 30 x DFB 14-1) to 1.65 per cent (IC $598958 \times$ DFB14-1) over $\mathrm{SV}_{1}$ and from -3.08 per cent (EC $329706 \mathrm{x}$ DFB 14-1, HB $30 \times$ DFB 14-1) to 1.90 per cent (IC 598958 x DFB14-1) over $\mathrm{SV}_{2}$. Out of forty five crosses, fifteen exhibited negative and significant heterosis over BP. Fourteen and thirteen crosses possessed negative and significant heterosis over $\mathrm{SV}_{1}$ and $\mathrm{SV}_{2}$ respectively. Plant height is an important yield component trait as with plant height increases the number of podded nodes and therefore increases the number of pods which contributes positively towards yield enhancement in faba bean. The range of heterosis for plant height was from -19.80 (EC 263620 x DFB 14-1) to 29.96 per cent (EC $454751 \times$ HB 09-16) over BP, from 16.00 (EC $263620 \times$ DFB 14-1) to 27.17 per cent (EC $454751 \times \mathrm{HB}$ 09-16) over $\mathrm{SV}_{1}$ and from -8.37 (EC $263620 \times$ DFB 14-1) to 38.73 per cent (EC 454751 x HB 09-16)) over $\mathrm{SV}_{2}$. The estimates of mean heterosis over BP, $\mathrm{SV}_{1}$ and $\mathrm{SV}_{2}$ were $-0.63,2.70$ and 12.03 per cent, respectively. Positive heterosis is highly desirable in the trait number of branches per plant and in the present study heterobeltiosis ranged from -33.33 (EC $25085 \times$ HB 9-16) to 71.43 per cent (HB $30 \times$ DFB 14-1). The standard heterosis over $\mathrm{SV}_{1}$ varied from 17.02 (EC 243626 x DFB 14-1, EC 10719 x HB 9-16, HB $30 \times$ HB 9-16) to 53.19 per cent (HB 30 x DFB 14-1) while over $\mathrm{SV}_{2}$ it ranged from -7.14 (EC $243626 \times$ DFB 14-1, EC $10719 \times$ HB 9-16, HB $30 \times$ HB 9-16) to 71.43 per cent (HB $30 \times$ DFB 14-1). The estimates of mean heterosis of these forty five hybrids were $7.66,14.14$ and 27.73 per cent for BP, $\mathrm{SV}_{1}$ and $\mathrm{SV}_{2}$, respectively. Eighteen crosses showed positive and significant value of heterobeltiosis for number of branches per 
plant. Out of 45 crosses, twenty five and thirty five crosses exhibited significant and positive heterosis over $\mathrm{SV}_{1}$ and $\mathrm{SV}_{2}$, respectively. The heterobeltiosis for number of pods per plant ranged from -36.20 (IC 5989588 x DFB 14-1) to 75.68 per cent (HB 30 x HB 09-15). The standard heterosis over $\mathrm{SV}_{1}$ varied from -32.21 (IC $598958 \times$ DFB 14-1) to 50.96 per cent (EC 454751 x HB 0916) while it ranged from -26.56 (IC $598958 \mathrm{x}$ DFB 14-1) to 63.54 per cent (EC $454751 \mathrm{x}$ $\mathrm{HB}$ 09-16) over $\mathrm{SV}_{2}$. The mean heterosis of forty five hybrids were 15.09 per cent, 6.03 per cent and 14.86 per cent for $\mathrm{BP}, \mathrm{SV}_{1}$ and $\mathrm{SV}_{2}$, respectively. Twenty one crosses showed positive and significant heterosis over BP., nineteen over $\mathrm{SV}_{1}$ and twenty two crosses over $\mathrm{SV}_{2}$.

In the present study, the trait pod length was included and observed as a yield component trait, positive heterosis in which might positively affect the overall seed yield. Heterobeltiosis for the character ranged from -38.67 (IC $374731 \times \mathrm{HB} 9-16$ ) to 30.87 per cent (EC $263620 \times$ HB 9-16) with mean heterosis of -10.94 per cent. The seven crosses showed positive and significant heterosis for pod length over BP. The standard heterosis over $\mathrm{SV}_{1}$ varied from 15.63 per cent (IC $374731 \times \mathrm{HB}$ 9-16) to 66.67 per cent (EC 263620 x HB 9-16) with a mean heterosis of 17.76 per cent. Twenty nine crosses exhibiting positive and significant standard heterosis over $\mathrm{SV}_{1}$. The standard heterosis over $\mathrm{SV}_{2}$ varied from -13.98 (IC $374731 \times \mathrm{HB} 9-16)$ to 69.92 per cent (EC $263620 \times$ HB 9-16) with the mean heterosis of 20.05 per cent. Thirty crosses exhibited significant and positive estimates of standard heterosis for pod length over $\mathrm{SV}_{2}$. The mean heterosis for number of seeds per pod over better-parent and standard varieties $\left(\mathrm{SV}_{1}\right.$ and $\mathrm{SV}_{2}$ ) was $-0.80,5.79$ and -4.12 per cent, respectively. The magnitude of heterobeltiosis varied from -25.00 (EC 329627 x DFB 14-1) to 33.33 per cent (IC $598958 \times$ HB 09-16, EC $263620 \times$ HB 9-16). The estimates of heterosis over $\mathrm{SV}_{1}$ ranged from -5.89 (IC 374731 x HB 09-16) to 33.33 per cent (IC 598958 x HB 09-16, EC 263620 x HB 9-16), whereas it was varied from -14.70 (IC 374731 x HB 09-16) to 20.85 per cent (IC 598958 x HB 09-16, EC 263620 x HB 9-16) over $\mathrm{SV}_{2}$. The lowest estimates of heterosis for biological yield per plant over BP (-39.32\%), $\mathrm{SV}_{1}(-30.74 \%)$ and $\mathrm{SV}_{2}(-30.17 \%)$ were estimated by the cross IC 598958 x DFB 14-1 in all three cases while the highest heterosis showed by the cross, HB 30 x HB 09-15 over BP (66.75 \%), EC 329706 x HB 09-16 over $\mathrm{SV}_{1}(35.25 \%)$ and EC 329706 x HB 09-16 over $\mathrm{SV}_{2}(36.36 \%)$.

Fifteen crosses showed positive and significant heterosis for biological yield per plant over better-parent. Eighteen crosses recorded positive and significant heterosis for biological yield per plant over $\mathrm{SV}_{1}$ and $\mathrm{SV}_{2}$ each. The heterosis for harvest index ranged from -20.64 (EC 10845 x HB 09-15) to 24.07 per cent (IC $598958 \times$ x H 09-16) over BP; from -16.92 per cent (EC 243626 x DFB 141) to 16.56 per cent (HB $50 \times \mathrm{HB} 09-16)$ over $\mathrm{SV}_{1}$ and from -15.16 (EC 243626 x DFB 141) to 19.02 per cent (HB 50 x HB 09-16) over $\mathrm{SV}_{2}$. The means of heterosis over $\mathrm{BP}, \mathrm{SV}_{1}$ and $\mathrm{SV}_{2}$ were $4.89,1.21$ and 3.34 per cent respectively. Twenty crosses showed significant and positive heterosis over BP. Twelve and seventeen crosses showed positive and significant heterosis over $\mathrm{SV}_{1}$ and $\mathrm{SV}_{2}$, respectively. The heterosis for 100seed weight ranged from -20.94 (EC 329627 $\mathrm{x}$ DFB 14-1) to 9.75 per cent (HB $10 \times \mathrm{HB}$ 09-16) over BP; from -16.22 (EC 329706 x HB 09-15) to 8.40 per cent (EC 329706 x HB 09-16) over $\mathrm{SV}_{1}$ and from -10.83 (EC 329706 $\mathrm{x}$ HB 09-15) to 15.38 per cent (EC $329706 \mathrm{x}$ $\mathrm{HB}$ 09-16) over $\mathrm{SV}_{2}$. The mean of heterosis were found $-6.15(\mathrm{BP}),-4.25\left(\mathrm{SV}_{1}\right)$ and 1.92 $\%$ (SV2).Six, five and twenty crosses showed 
significant and positive heterosis over BP, $\mathrm{SV}_{1}$ and $\mathrm{SV}_{2}$, respectively. The heterosis for protein content over BP ranged from -20.21 (IC $374731 \times$ DFB 14-1) to 31.39 per cent (EC 243626 x DFB 14-1); from -18.63 (EC $5873 \times$ DFB 14-1) to 14.59 per cent (IC 374731 x HB 09-15) over $\mathrm{SV}_{1}$ and from 20.38 (EC $5873 \times$ DFB 14-1) to 12.13 per cent (IC $374731 \times$ HB 09-15) over $\mathrm{SV}_{2}$. The means of heterosis were found -0.62 (BP), $1.48\left(\mathrm{SV}_{1}\right)$ and $-3.60 \%\left(\mathrm{SV}_{2}\right)$. Thirteen, eighteen and thirteen crosses showed significant and positive heterosis over BP, $\mathrm{SV}_{1}$ and $\mathrm{SV}_{2}$ respectively.

As in other crops, grain yield per plant is a complex trait in Faba bean also and improvement of seed yield remains the most important objective of the faba bean improvement programmes. Heterosis for grain yield per plant over BP ranged from -35.75 (IC 598958 x DFB 14-1) to 100.74 per cent (HB $30 \times$ HB 09-15) with the mean of heterosis was 11.66 per cent. Out of 45 crosses, sixteen emerged with positive and significant heterobeltiosis and the best five cross combinations were HB 30 x HB 915(100.74\%), EC $243626 \times$ HB 9-16 (63.82 $\%)$, HB 10 x HB 9-16 (61.69\%), HB 10 x HB 9-15 (61.30\%) and EC 454751 x DFB 141(43.09 \%). The heterosis over SV1 varied from -35.10 (IC $598958 \times$ DFB 14-1) to 46.30 per cent (EC 243626 x HB 9-16) with the mean of heterosis was 7.92 per cent. Nineteen crosses exhibited positive and significant heterosis over $\mathrm{SV}_{1}$ and the best five crosses among them were EC 243626 x HB 9-16 (46.30\%), HB $30 \times$ HB 9-15 (45.12\%), HB $50 \times$ HB 9-15 (41.28\%), HB $10 \times$ HB 9-16 (40.29\%) and HB $10 \times$ HB 9-15 (39.95\%). The range of heterosis over $\mathrm{SV}_{2}$ varied from 33.26 (IC $598958 \times$ DFB 14-1) to 50.46 per cent (EC 243626 x HB 9-16). Nineteen crosses exhibited positive and significant heterosis for grain yield per plant over $\mathrm{SV}_{2}$ and the best five crosses among them were
EC $243626 \times$ HB 9-16 (50.46\%), HB $30 \times$ HB 9-15 (49.25\%), HB 50 x HB 9-15 (45.30 $\%)$, HB $10 \times$ HB 9-16 (44.28 \%) and HB $10 \times$ HB 9-15 (43.93\%).

Faba bean (Vicia faba L.)exhibits both positive and negative significant heterosis over better parent and standard varieties in various characters. The fact that the traits on which observations were made and heterosis was estimated in this study constitutes the yield component traits were confirmed by the earlier studies carried out by Bishnoi et al., (2015). The mean performance of the parental genotypes of diverse origin and their hybrids differed significantly which is in agreement with Abdalla et al., (2015). Bishnoi et al., (2012) suggested that outcrossing is associated with increased seed yields in Faba bean. Significant negative and positive heterosis over better parent and standard varieties in plant height, number of branches per plant, number of pods per plant, number of seeds, 100-seed weight and grain yield per plant were observed by Zeinab and Helal (2014) and Bishnoiet al.,(2015) which are in agreement with the present study. Significant positive and negative heterosis relative to the better parent and standard varieties for the traits plant height, number of branches per plant, number of pods per plant, number of seeds per plant, grain yield per plant and 100seed weight is in agreement with Abdalla et al., (2015). Saad et al., (2015) observed significant positive and negative heterosis over better parent and standard varieties in number of days to 50 per cent flowering, significant negative heterosis in number of days to maturity, significant positive and negative heterosis in plant height, number of branches per plant, significant positive heterosis in number of pods per plant and significant negative heterosis in 100-seeds weight and concluded that in general, the results indicated that most crosses were significantly earlier and higher yielding than 
their better parent and standard varieties suggesting the important role of non-additive gene action in the inheritance of studied traits. The study is also in agreement with that of ElHady et al., (2007) who suggested that the heterotic effects in Vicia faba L. might range from significantly positive to significantly negative for different traits depending on genetic makeup of parents and with Link (2006) who observed that the $F_{1}$ hybrids of Faba bean out yielded their inbred parents by more than 30 per cent. El-Hadyet al., (2007) also suggested that the superiority of hybrids over the mid and better parents for seed yield is associated with the manifestations of the heterotic effects for yield component traits. Bishnoi et al., (2012) reviewed that positive and significant heterosis over mid-parent and better parent is exhibited by $F_{1}$ Faba bean hybrids for seed yield, number of stems per plant, number of branches per plant, first fruiting node, podded nodes and seeds per plant, number of pods per plant, number of seeds per pod, number of pods per node and seeds per pod, seed weight, plant height, and maturity date which varied according to cross combinations and trait. The present study is in full agreement with the observations made in the above mentioned study. The results of the present study indicate the presence of significant genetic variability among the genotypes used as parents reflected in their hybrid combinations which have exhibited both significantly positive and significantly negative heterosis over the better parent and standard varieties. The range of heterosis in various traits is quite wide which represents the degree of heterozygosity and genetic divergence among the parents.

The heterosis breeding has been used extensively in improving yield potential through development of hybrid cultivars in most of the often cross pollinated crops. The presence of high heterosis for economically important characters is not only useful for developing hybrids, synthetic or composites through exploitation of heterosis, but also helps in obtaining transgressive segregants for development of superior inbred lines. Besides, grain yield, substantial heterosis over betterparent and standard varieties was also observed in negative as well as positive direction for different characters (Table 2). However, the number of crosses showing significant estimates and the range of heterosis varied from one character to another. The mean heterosis was both in positive and negative direction for different characters. In general, some crosses showed appreciable and high heterosis for most of the characters under study. The existence of wide spectrum of heterosis in either direction with expression of high degree of desirable heterosis by some crosses for most of the characters observed in present study is in conformity with the earlier reports for such characters in faba bean (El-Harty et al., 2007; Alghamdi, 2009; Ibrahim, 2010; Mourad, 2011; Farag and Afiah, 2012; Abd-El rahman et al., 2012; Bakhit and Abdel-Fatah, 2013; Obiadalla-Ali et al., 2013; Zeinab and ElEmam, 2013; El-Banna et al., 2014; Zeinab and Helal, 2014; Ashrei et al., 2014; Bishnoi et al., 2015; 2017).

It was also noted that higher heterosis over better-parent, $\mathrm{SV}_{1}$ and $\mathrm{SV}_{2}$ was found in some lower yielding crosses when compared to other crosses which have displayed high yield. This suggested that while selecting the best hybrid, besides the heterotic response over better parent, $\mathrm{SV}_{1}$ and $\mathrm{SV}_{2}$, the mean performance of the crosses should also be given due consideration. Since, heterosis estimates result from $\mathrm{F}_{1}-\mathrm{BP}, \mathrm{F}_{1}-\mathrm{SV}_{1}$ and $\mathrm{F}_{1^{-}}$ $\mathrm{SV}_{2}$; and depend more or less on the mean of the parents in question, there is every possibility of getting a cross with lower mean performance but high heterotic response, in case the parental performance is very poor. 
Table.1 Mean performance, general mean, range, coefficient of variation, critical difference and standard error for 12 characters of line $\mathrm{x}$ tester set of $45 \mathrm{~F}_{1}$ 's and their 18 parents along with two checks

\begin{tabular}{|c|c|c|c|c|c|c|c|c|c|c|c|c|c|}
\hline $\begin{array}{l}\text { Sl. } \\
\text { No. }\end{array}$ & Crosses/Genotypes/Checks & $\begin{array}{l}\text { Days to } \\
50 \% \\
\text { flowering }\end{array}$ & $\begin{array}{l}\text { Days to } \\
\text { maturity }\end{array}$ & $\begin{array}{l}\text { Plant } \\
\text { height } \\
(\mathrm{cm})\end{array}$ & $\begin{array}{l}\text { Number } \\
\text { of } \\
\text { branches } \\
\text { per } \\
\text { plant }\end{array}$ & $\begin{array}{l}\text { Number } \\
\text { of pods } \\
\text { per } \\
\text { plant }\end{array}$ & $\begin{array}{l}\text { Pod } \\
\text { length } \\
\text { (cm) }\end{array}$ & $\begin{array}{l}\text { Number } \\
\text { of seeds } \\
\text { per pod }\end{array}$ & $\begin{array}{l}\text { Biological } \\
\text { yield per } \\
\text { plant (g) }\end{array}$ & $\begin{array}{l}\text { Harvest } \\
\text { Index } \\
(\%)\end{array}$ & $\begin{array}{l}100- \\
\text { seed } \\
\text { weight } \\
\text { (g) }\end{array}$ & $\begin{array}{l}\text { Protein } \\
\text { content } \\
(\%)\end{array}$ & $\begin{array}{l}\text { Grain } \\
\text { yield } \\
\text { per } \\
\text { plant } \\
\text { (g) }\end{array}$ \\
\hline & & 1 & 2 & 3 & 4 & 5 & 6 & 7 & 8 & 9 & 10 & 11 & 12 \\
\hline 1 & EC 243626 x DFB 14-1 & 71.67 & 142.00 & 84.95 & 2.60 & 9.67 & 4.85 & 3.07 & 27.40 & 30.14 & 29.04 & 27.21 & 8.27 \\
\hline 2 & EC 243626 x HB 9-15 & 69.00 & 139.67 & 88.89 & 3.20 & 14.33 & 5.08 & 3.13 & 33.73 & 38.36 & 29.71 & 21.38 & 12.95 \\
\hline 3 & EC 243626 x HB 9-16 & 66.00 & 136.67 & 98.89 & 4.60 & 19.07 & 6.11 & 3.31 & 43.60 & 39.62 & 28.64 & 21.22 & 17.28 \\
\hline 4 & EC 329706 x DFB 14-1 & 65.33 & 136.33 & 83.11 & 3.80 & 15.60 & 3.57 & 3.00 & 32.00 & 36.50 & 26.70 & 21.66 & 11.69 \\
\hline 5 & EC 329706 x HB 9-15 & 69.67 & 140.33 & 87.22 & 3.20 & 16.93 & 3.70 & 3.04 & 32.73 & 37.82 & 25.01 & 23.51 & 12.38 \\
\hline 6 & EC 329706 x HB 9-16 & 71.00 & 140.00 & 102.44 & 4.40 & 17.60 & 3.45 & 2.82 & 44.00 & 34.79 & 32.36 & 26.97 & 15.32 \\
\hline 7 & EC 301470 x DFB 14-1 & 71.00 & 141.00 & 94.33 & 3.60 & 16.47 & 5.01 & 3.31 & 38.40 & 39.84 & 29.00 & 19.62 & 15.30 \\
\hline 8 & EC $301470 \times$ HB 9-15 & 70.00 & 139.00 & 88.45 & 4.60 & 19.40 & 4.79 & 3.18 & 39.40 & 39.59 & 27.00 & 27.44 & 15.62 \\
\hline 9 & EC 301470 x HB 9-16 & 71.00 & 141.00 & 96.22 & 3.60 & 14.47 & 4.96 & 3.18 & 32.00 & 39.72 & 29.66 & 24.90 & 12.73 \\
\hline 10 & EC 454751 x DFB 14-1 & 71.33 & 142.00 & 103.11 & 3.80 & 19.07 & 4.96 & 2.93 & 42.20 & 37.72 & 30.15 & 26.95 & 15.94 \\
\hline 11 & EC 454751 x HB 9-15 & 71.33 & 141.00 & 105.89 & 3.60 & 17.40 & 4.61 & 2.82 & 40.60 & 35.09 & 30.18 & 20.96 & 14.26 \\
\hline 12 & EC $454751 \times$ HB 9-16 & 69.00 & 138.33 & 108.67 & 3.80 & 20.93 & 4.63 & 3.10 & 40.47 & 38.68 & 26.85 & 21.09 & 15.68 \\
\hline 13 & EC 263620 x DFB 14-1 & 68.00 & 137.00 & 71.78 & 3.00 & 11.13 & 5.81 & 3.31 & 26.73 & 38.54 & 28.43 & 25.71 & 10.32 \\
\hline 14 & EC $263620 \times$ HB 9-15 & 68.67 & 138.00 & 76.95 & 3.40 & 12.13 & 5.44 & 3.00 & 30.27 & 36.31 & 31.25 & 23.83 & 11.02 \\
\hline 15 & EC 263620 x HB 9-16 & 70.33 & 139.00 & 74.55 & 3.20 & 12.47 & 6.68 & 4.00 & 35.07 & 41.03 & 29.60 & 22.77 & 14.42 \\
\hline 16 & EC 5873 x DFB $14-1$ & 69.67 & 138.67 & 73.33 & 2.80 & 10.13 & 4.56 & 3.00 & 25.27 & 33.11 & 28.60 & 19.54 & 8.38 \\
\hline 17 & EC5873 x HB 9-15 & 68.00 & 137.00 & 73.22 & 3.80 & 12.60 & 4.98 & 2.97 & 30.93 & 32.92 & 27.87 & 27.18 & 10.20 \\
\hline 18 & EC 5873 x HB 9-16 & 69.00 & 138.00 & 90.89 & 3.40 & 12.40 & 4.23 & 3.00 & 31.07 & 34.06 & 28.85 & 25.22 & 10.62 \\
\hline 19 & EC $10719 \times$ DFB $14-1$ & 69.00 & 138.00 & 78.28 & 3.40 & 12.67 & 5.26 & 3.20 & 30.40 & 37.54 & 29.09 & 24.75 & 11.43 \\
\hline 20 & EC $10719 \times$ HB 9-15 & 71.00 & 141.33 & 84.44 & 3.33 & 12.00 & 5.20 & 3.40 & 30.13 & 37.53 & 28.22 & 22.97 & 11.32 \\
\hline 21 & EC 10719 x HB 9-16 & 71.00 & 141.00 & 73.56 & 2.60 & 13.33 & 4.56 & 3.20 & 29.13 & 37.26 & 26.06 & 20.93 & 10.88 \\
\hline 22 & EC 329627 x DFB 14-1 & 69.00 & 139.33 & 74.72 & 2.80 & 13.40 & 4.16 & 3.00 & 28.53 & 35.37 & 25.80 & 27.01 & 10.11 \\
\hline 23 & EC 329627 x HB 9-15 & 67.00 & 138.00 & 84.61 & 3.60 & 15.00 & 5.04 & 3.42 & 38.07 & 37.72 & 29.61 & 21.27 & 14.36 \\
\hline 24 & EC 329627 x HB 9-16 & 70.00 & 141.00 & 77.22 & 3.20 & 12.60 & 4.54 & 3.31 & 27.00 & 39.00 & 26.03 & 21.07 & 10.53 \\
\hline 25 & EC 25085 x DFB $14-1$ & 69.00 & 140.00 & 86.22 & 3.20 & 13.60 & 4.46 & 3.31 & 33.20 & 35.14 & 26.65 & 21.92 & 11.68 \\
\hline 26 & EC 25085 x HB 9-15 & 72.00 & 141.00 & 87.72 & 3.80 & 11.07 & 4.35 & 3.00 & 29.93 & 32.26 & 30.27 & 23.54 & 9.67 \\
\hline 27 & EC $25085 \times$ HB 9-16 & 71.00 & 141.67 & 81.89 & 2.80 & 13.00 & 4.50 & 3.20 & 31.33 & 38.11 & 29.87 & 26.91 & 11.97 \\
\hline 28 & HB 10 x DFB $14-1$ & 72.00 & 142.00 & 101.64 & 3.40 & 19.40 & 4.82 & 3.11 & 39.13 & 36.25 & 25.42 & 24.94 & 14.20 \\
\hline
\end{tabular}




\begin{tabular}{|c|c|c|c|c|c|c|c|c|c|c|c|c|c|}
\hline 29 & HB $10 \times$ HB 9-15 & 72.00 & 141.67 & 98.00 & 4.20 & 17.60 & 5.60 & 3.31 & 42.07 & 39.28 & 30.20 & 23.03 & 16.53 \\
\hline 30 & HB $10 \times$ HB 9-16 & 71.00 & 141.33 & 107.56 & 4.00 & 17.60 & 4.29 & 3.22 & 43.60 & 37.99 & 31.45 & 20.98 & 16.57 \\
\hline 31 & HB $30 \times$ DFB $14-1$ & 68.00 & 136.33 & 104.33 & 4.80 & 15.40 & 3.91 & 3.07 & 38.80 & 33.02 & 27.85 & 21.74 & 12.83 \\
\hline 32 & HB 30 x HB 9-15 & 71.00 & 141.00 & 93.89 & 4.20 & 17.33 & 5.54 & 3.44 & 42.47 & 40.35 & 30.67 & 23.54 & 17.14 \\
\hline 33 & HB 30 x HB 9-16 & 70.00 & 140.33 & 91.11 & 2.60 & 10.40 & 4.14 & 3.00 & 25.60 & 32.60 & 27.10 & 26.66 & 8.36 \\
\hline 34 & HB 50 x DFB $14-1$ & 71.00 & 141.00 & 101.78 & 3.60 & 17.93 & 3.46 & 2.99 & 39.93 & 37.12 & 28.16 & 25.94 & 14.83 \\
\hline 35 & HB $50 \times$ HB 9-15 & 70.67 & 141.00 & 101.33 & 4.00 & 20.60 & 3.98 & 2.98 & 42.47 & 39.26 & 28.05 & 23.89 & 16.69 \\
\hline 36 & HB 50 x HB 9-16 & 71.67 & 142.00 & 92.78 & 3.80 & 15.80 & 6.16 & 3.69 & 36.27 & 42.28 & 28.60 & 22.73 & 15.35 \\
\hline 37 & IC $598958 \times$ DFB $14-1$ & 72.00 & 143.33 & 73.89 & 3.00 & 9.40 & 3.80 & 2.82 & 22.53 & 33.99 & 30.25 & 25.81 & 7.67 \\
\hline 38 & IC $598958 \times$ HB 9-15 & 72.00 & 140.00 & 78.95 & 3.60 & 15.40 & 4.28 & 3.07 & 34.73 & 38.16 & 29.02 & 23.91 & 13.26 \\
\hline 39 & IC $598958 \times$ HB 9-16 & 70.00 & 140.00 & 77.89 & 2.80 & 12.20 & 6.54 & 4.00 & 34.53 & 39.74 & 28.43 & 22.75 & 13.75 \\
\hline 40 & IC $374731 \times$ DFB 14-1 & 67.67 & 138.00 & 80.44 & 4.60 & 11.80 & 5.46 & 3.56 & 32.33 & 35.15 & 27.52 & 19.58 & 11.37 \\
\hline 41 & IC 374731 x HB 9-15 & 68.00 & 138.00 & 83.45 & 4.20 & 15.60 & 4.19 & 3.27 & 36.87 & 37.36 & 27.74 & 27.51 & 13.78 \\
\hline 42 & IC $374731 \times$ HB 9-16 & 69.00 & 138.33 & 76.72 & 3.80 & 16.47 & 3.38 & 2.82 & 38.13 & 33.52 & 28.46 & 25.03 & 12.79 \\
\hline 43 & EC $10845 \times$ DFB $14-1$ & 71.00 & 141.33 & 87.45 & 4.00 & 12.60 & 4.92 & 3.18 & 32.40 & 32.58 & 27.15 & 24.98 & 10.58 \\
\hline 44 & EC $10845 \times$ HB 9-15 & 68.33 & 140.00 & 86.78 & 3.00 & 12.00 & 3.82 & 3.00 & 32.53 & 30.19 & 28.55 & 22.94 & 9.83 \\
\hline 45 & EC $10845 \times$ HB 9-16 & 72.00 & 142.67 & 79.45 & 4.20 & 15.60 & 4.70 & 3.07 & 35.00 & 39.49 & 31.16 & 20.99 & 13.83 \\
\hline \multicolumn{2}{|r|}{ Mean } & 69.92 & 139.88 & 87.76 & 3.58 & 14.70 & 4.72 & 3.17 & 34.51 & 36.71 & 28.58 & 23.65 & 12.75 \\
\hline 46 & EC 243626 & 71.00 & 141.00 & 88.56 & 3.00 & 11.60 & 4.52 & 3.20 & 32.07 & 32.92 & 29.44 & 20.60 & 10.55 \\
\hline 47 & EC 329706 & 66.67 & 137.33 & 82.89 & 3.00 & 12.73 & 5.46 & 3.00 & 33.73 & 33.00 & 29.99 & 26.91 & 11.15 \\
\hline 48 & EC 301470 & 71.00 & 140.33 & 84.89 & 3.40 & 11.80 & 6.25 & 3.40 & 34.00 & 36.47 & 32.57 & 20.75 & 12.40 \\
\hline 49 & EC 454751 & 72.00 & 142.00 & 81.44 & 4.00 & 13.73 & 4.84 & 3.20 & 32.67 & 34.05 & 28.04 & 23.08 & 11.14 \\
\hline 50 & EC 263620 & 70.00 & 140.33 & 89.50 & 3.20 & 12.80 & 5.11 & 3.00 & 33.40 & 34.38 & 31.09 & 25.42 & 11.48 \\
\hline 51 & EC 5873 & 71.67 & 142.00 & 83.61 & 3.40 & 11.47 & 4.90 & 3.00 & 32.80 & 28.75 & 28.40 & 23.56 & 9.45 \\
\hline 52 & EC 10719 & 71.00 & 141.00 & 90.28 & 3.80 & 11.33 & 6.63 & 3.80 & 36.60 & 36.84 & 32.83 & 22.38 & 13.48 \\
\hline 53 & EC 329627 & 71.00 & 142.00 & 88.89 & 3.80 & 9.20 & 5.90 & 4.00 & 34.33 & 33.18 & 32.64 & 19.17 & 11.40 \\
\hline 54 & EC 25085 & 68.00 & 139.00 & 83.22 & 4.20 & 15.67 & 4.78 & 2.82 & 33.93 & 34.53 & 27.87 & 26.39 & 11.73 \\
\hline 55 & HB 10 & 66.00 & 135.67 & 91.95 & 2.80 & 12.40 & 4.42 & 3.00 & 28.53 & 35.87 & 28.66 & 21.34 & 10.25 \\
\hline 56 & HB 30 & 66.00 & 136.00 & 81.89 & 2.80 & 9.87 & 5.49 & 3.11 & 22.93 & 37.23 & 28.25 & 26.54 & 8.54 \\
\hline 57 & HB 50 & 65.00 & 135.00 & 92.39 & 2.80 & 13.40 & 5.07 & 3.53 & 35.73 & 38.01 & 29.85 & 20.95 & 13.58 \\
\hline 58 & IC 598958 & 70.67 & 140.67 & 86.61 & 2.60 & 14.73 & 5.41 & 3.00 & 37.13 & 32.03 & 29.41 & 24.97 & 11.93 \\
\hline 59 & IC 374731 & 71.00 & 140.00 & 90.78 & 3.50 & 14.07 & 5.52 & 3.00 & 36.20 & 36.98 & 33.97 & 24.54 & 13.40 \\
\hline 60 & EC 10845 & 70.00 & 139.33 & 89.95 & 3.20 & 14.40 & 5.08 & 3.20 & 34.27 & 37.99 & 28.45 & 22.67 & 13.02 \\
\hline 61 & DFB 14-1 & 72.00 & 141.67 & 87.56 & 2.80 & 12.13 & 5.15 & 2.93 & 27.60 & 33.30 & 27.46 & 20.71 & 9.20 \\
\hline 62 & HB 9-15 & 71.00 & 141.33 & 87.00 & 3.20 & 9.73 & 3.63 & 2.82 & 25.47 & 32.29 & 30.99 & 23.26 & 8.23 \\
\hline 63 & HB 9-16 & 69.00 & 138.67 & 83.61 & 3.00 & 12.00 & 4.75 & 3.00 & 25.53 & 31.39 & 22.97 & 22.87 & 8.03 \\
\hline \multicolumn{2}{|r|}{ Mean } & 69.61 & 139.63 & 86.94 & 3.25 & 12.39 & 5.16 & 3.17 & 32.05 & 34.40 & 29.61 & 23.12 & 11.05 \\
\hline
\end{tabular}




\begin{tabular}{|c|c|c|c|c|c|c|c|c|c|c|c|c|c|}
\hline \multicolumn{2}{|c|}{ General Mean } & 69.83 & 139.81 & 87.52 & 3.48 & 14.04 & 4.85 & 3.17 & 33.81 & 36.05 & 28.88 & 23.50 & 12.26 \\
\hline \multirow[t]{2}{*}{ Range } & Lowest & 65.00 & 135.00 & 71.78 & 2.60 & 9.20 & 3.38 & 2.82 & 22.53 & 28.75 & 22.97 & 19.17 & 7.67 \\
\hline & Highest & 72.00 & 143.33 & 108.67 & 4.80 & 20.93 & 6.68 & 4.00 & 44.00 & 42.28 & 33.97 & 27.51 & 17.28 \\
\hline \multirow[t]{2}{*}{ Checks } & HFB 1 C & 70.00 & 141.00 & 85.45 & 3.13 & 13.87 & 4.01 & 3.00 & 32.53 & 36.28 & 29.85 & 24.01 & 11.81 \\
\hline & Vikrant (C) & 69.00 & 140.67 & 78.33 & 2.80 & 12.80 & 3.93 & 3.31 & 32.27 & 35.53 & 28.05 & 24.54 & 11.49 \\
\hline \multicolumn{2}{|c|}{ C.V. } & 1.64 & 0.92 & 1.93 & 5.92 & 7.37 & 5.23 & 5.25 & 5.77 & 4.41 & 1.26 & 1.77 & 9.18 \\
\hline \multicolumn{2}{|c|}{ F ratio } & 7.64 & 6.64 & 90.34 & 22.77 & 23.48 & 29.62 & 8.28 & 21.97 & 10.26 & 88.60 & 94.29 & 14.58 \\
\hline \multicolumn{2}{|c|}{ S.E. } & 0.66 & 0.74 & 0.97 & 0.12 & 0.60 & 0.15 & 0.10 & 1.12 & 0.92 & 0.21 & 0.24 & 0.65 \\
\hline \multicolumn{2}{|c|}{ C.D. $5 \%$} & 1.85 & 2.07 & 2.72 & 0.33 & 1.67 & 0.41 & 0.27 & 3.15 & 2.57 & 0.59 & 0.67 & 1.82 \\
\hline \multicolumn{2}{|c|}{ C.D. $1 \%$} & 2.44 & 2.74 & 3.59 & 0.44 & 2.21 & 0.54 & 0.36 & 4.16 & 3.40 & 0.78 & 0.89 & 2.40 \\
\hline
\end{tabular}

Table.2 Extent of per cent heterosis over better parent (BP) and two standard varieties $\left(\mathrm{SV}_{1}\right.$ and $\left.\mathrm{SV}_{2}\right)$ for 12 characters in faba bean (Vicia faba L.)

\begin{tabular}{|c|c|c|c|c|c|c|c|c|c|c|c|c|c|}
\hline \multirow{2}{*}{$\begin{array}{c}\text { S. } \\
\text { No. }\end{array}$} & \multirow[t]{2}{*}{ Crosses } & \multicolumn{3}{|c|}{ Days to $50 \%$ flowering } & \multicolumn{3}{|c|}{ Days to maturity } & \multicolumn{3}{|c|}{ Plant height (cm) } & \multicolumn{3}{|c|}{ Number of branches per plant } \\
\hline & & BP & $\mathrm{SV}_{1}$ & $\mathbf{S V}_{2}$ & BP & $\mathrm{SV}_{1}$ & $\mathrm{SV}_{2}$ & BP & $\mathrm{SV}_{1}$ & $\mathrm{SV}_{2}$ & BP & $\mathrm{SV}_{1}$ & $\mathrm{SV}_{2}$ \\
\hline 1 & EC 243626 x DFB $14-1$ & -0.46 & 2.38 & $3.86 * *$ & 0.24 & 0.71 & 0.95 & $-4.08 *$ & -0.59 & $8.45 * *$ & $-13.33^{*}$ & $-17.02 * *$ & -7.14 \\
\hline 2 & EC $243626 \times$ HB 9-15 & $-2.82 *$ & -1.43 & 0.00 & -1.18 & -0.95 & -0.71 & 0.38 & $4.03 *$ & $13.48 * *$ & 0.00 & 2.13 & $14.29 *$ \\
\hline 3 & EC $243626 \times$ HB 9-16 & $-7.04 * *$ & $-5.71 * *$ & $-4.35 * *$ & $-3.07 * *$ & $-3.07 * *$ & $-2.84 * *$ & $11.67 * *$ & $15.73 * *$ & $26.25 * *$ & $53.33 * *$ & $46.81 * *$ & $64.29 * *$ \\
\hline 4 & EC 329706 x DFB 14-1 & $-9.26 * *$ & $-6.67 * *$ & $-5.31 * *$ & $-3.76 * *$ & $-3.31 * *$ & $-3.08 * *$ & $-5.08 * *$ & -2.73 & $6.10 * *$ & $26.67 * *$ & $21.28 * *$ & $35.71 * *$ \\
\hline 5 & EC $329706 \times$ HB 9-15 & -1.88 & -0.48 & 0.97 & -0.71 & -0.47 & -0.24 & 0.26 & 2.08 & $11.35 * *$ & 0.00 & 2.13 & $14.29 *$ \\
\hline 6 & EC $329706 \times$ HB 9-16 & $2.90 *$ & 1.43 & $2.90^{*}$ & 0.96 & -0.71 & -0.47 & $22.52 * *$ & $19.89 * *$ & $30.78 * *$ & $46.67 * *$ & $40.43 * *$ & $57.14 * *$ \\
\hline 7 & EC $301470 \times$ DFB $14-1$ & -1.39 & 1.43 & $2.90^{*}$ & -0.47 & 0.00 & 0.24 & $7.74 * *$ & $10.40 * *$ & $20.43 * *$ & 5.88 & $14.89 * *$ & $28.57 * *$ \\
\hline 8 & EC $301470 \times$ HB 9-15 & -1.41 & 0.00 & 1.45 & $-1.65^{*}$ & -1.42 & -1.18 & 1.66 & $3.51 *$ & $12.92 * *$ & $35.29 * *$ & $46.81 * *$ & $64.29 * *$ \\
\hline 9 & EC $301470 \times$ HB 9-16 & 0.00 & 1.43 & $2.90 *$ & 0.48 & 0.00 & 0.24 & $13.35 * *$ & $12.61 * *$ & $22.84 * *$ & 5.88 & $14.89 * *$ & $28.57 * *$ \\
\hline 10 & EC $454751 \times$ DFB $14-1$ & -0.93 & 1.90 & $3.38 *$ & 0.00 & 0.71 & 0.95 & $17.77 * *$ & $20.68 * *$ & $31.64 * *$ & -5.00 & $21.28 * *$ & $35.71 * *$ \\
\hline 11 & EC $454751 \times$ HB 9-15 & -0.93 & 1.90 & $3.38 *$ & -0.70 & 0.00 & 0.24 & $21.71 * *$ & $23.93 * *$ & $35.18 * *$ & $-10.00 *$ & $14.89 * *$ & $28.57 * *$ \\
\hline 12 & EC $454751 \times$ HB 9-16 & $-4.17 * *$ & -1.43 & 0.00 & $-2.58 * *$ & $-1.89 *$ & $-1.66^{*}$ & $29.96 * *$ & $27.17 * *$ & $38.73 * *$ & -5.00 & $21.28 * *$ & $35.71 * *$ \\
\hline 13 & EC 263620 x DFB $14-1$ & $-5.56 * *$ & $-2.86^{*}$ & -1.45 & $-3.29 * *$ & $-2.84 * *$ & $-2.61 * *$ & $-19.80 * *$ & $-16.00 * *$ & $-8.37 * *$ & -6.25 & -4.26 & 7.14 \\
\hline 14 & EC $263620 \times$ HB 9-15 & $-3.29 *$ & -1.90 & -0.48 & $-2.36 * *$ & $-2.13 * *$ & $-1.90 *$ & $-14.03 * *$ & $-9.95 * *$ & -1.77 & 6.25 & 8.51 & $21.43 * *$ \\
\hline 15 & EC $263620 \times$ HB 9-16 & 0.48 & 0.48 & 1.93 & -0.95 & -1.42 & -1.18 & $-16.70 * *$ & $-12.75 * *$ & $-4.82 * *$ & 0.00 & 2.13 & $14.29 *$ \\
\hline 16 & EC 5873 x DFB 14-1 & $-3.24 *$ & -0.48 & 0.97 & $-2.35 * *$ & $-1.65^{*}$ & -1.42 & $-16.24 * *$ & $-14.18 * *$ & $-6.38 * *$ & $-17.65 * *$ & $-10.64 *$ & 0.00 \\
\hline 17 & EC5873 x HB 9-15 & $-5.12 * *$ & $-2.86^{*}$ & -1.45 & $-3.52 * *$ & $-2.84 * *$ & $-2.61 * *$ & $-15.84 * *$ & $-14.31 * *$ & $-6.52 * *$ & $11.76^{*}$ & $21.28 * *$ & $35.71 * *$ \\
\hline 18 & EC $5873 \times$ HB 9-16 & $-3.72 * *$ & -1.43 & 0.00 & $-2.82 * *$ & $-2.13 * *$ & $-1.90^{*}$ & $8.70 * *$ & $6.37 * *$ & $16.03 * *$ & 0.00 & 8.51 & $21.43 * *$ \\
\hline 19 & EC 10719 x DFB 14-1 & $-4.17 * *$ & -1.43 & 0.00 & $-2.59 * *$ & $-2.13 * *$ & $-1.90 *$ & $-13.29 * *$ & $-8.39 * *$ & -0.07 & $-10.53 *$ & 8.51 & $21.43 * *$ \\
\hline
\end{tabular}




\begin{tabular}{|c|c|c|c|c|c|c|c|c|c|c|c|c|c|}
\hline 20 & EC 10719 x HB 9-15 & 0.00 & 1.43 & $2.90^{*}$ & 0.00 & 0.24 & 0.47 & $-6.46 * *$ & -1.17 & $7.80 * *$ & $-12.28 * *$ & 6.38 & $19.05^{* *}$ \\
\hline 21 & EC 10719 x HB 9-16 & 0.00 & 1.43 & $2.90 *$ & 0.00 & 0.00 & 0.24 & $-18.52 * *$ & $-13.92 * *$ & $-6.09 * *$ & $-31.58 * *$ & $-17.02 * *$ & -7.14 \\
\hline 22 & EC $329627 \times$ DFB 14-1 & $-4.17 * *$ & -1.43 & 0.00 & $-1.88 *$ & -1.18 & -0.95 & $-15.94 * *$ & $-12.55 * *$ & $-4.61 *$ & $-26.32 * *$ & $-10.64 *$ & 0.00 \\
\hline 23 & EC 329627 x HB 9-15 & $-5.63 * *$ & $-4.29 * *$ & $-2.90 *$ & $-2.82 * *$ & $-2.13 * *$ & $-1.90 *$ & $-4.81 * *$ & -0.98 & $8.02 * *$ & -5.26 & $14.89 * *$ & $28.57 * *$ \\
\hline 24 & EC 329627 x HB 9-16 & -1.41 & 0.00 & 1.45 & -0.70 & 0.00 & 0.24 & $-13.12 * *$ & $-9.62 * *$ & -1.41 & $-15.79 * *$ & 2.13 & $14.29 *$ \\
\hline 25 & EC 25085 x DFB 14-1 & $-4.17 * *$ & -1.43 & 0.00 & -1.18 & -0.71 & -0.47 & -1.53 & 0.91 & $10.07 * *$ & $-23.81 * *$ & 2.13 & $14.29 *$ \\
\hline 26 & EC $25085 \times$ HB 9-15 & 1.41 & $2.86^{*}$ & $4.35^{* *}$ & -0.24 & 0.00 & 0.24 & 0.83 & 2.66 & $11.99 * *$ & $-9.52 *$ & $21.28 * *$ & $35.71 * *$ \\
\hline 27 & EC $25085 \times$ HB 9-16 & $2.90 *$ & 1.43 & $2.90 *$ & $1.92 *$ & 0.47 & 0.71 & -2.06 & $-4.16^{*}$ & $4.54 *$ & $-33.33 * *$ & $-10.64 *$ & 0.00 \\
\hline 28 & HB 10 x DFB 14-1 & 0.00 & $2.86^{*}$ & $4.35 * *$ & 0.24 & 0.71 & 0.95 & $10.54 * *$ & $18.95 * *$ & $29.75 * *$ & $21.43 * *$ & 8.51 & $21.43 * *$ \\
\hline 29 & HB 10 x HB 9-15 & 1.41 & $2.86 *$ & $4.35^{* *}$ & 0.24 & 0.47 & 0.71 & $6.58 * *$ & $14.69 * *$ & $25.11 * *$ & $31.25 * *$ & $34.04 * *$ & $50.00 * *$ \\
\hline 30 & HB $10 \times$ HB 9-16 & $2.90 *$ & 1.43 & $2.90 *$ & $1.92 *$ & 0.24 & 0.47 & $16.98 * *$ & $25.88 * *$ & $37.31 * *$ & $33.33 * *$ & $27.66 * *$ & $42.86^{* *}$ \\
\hline 31 & HB $30 \times$ DFB $14-1$ & $-5.56 * *$ & $-2.86^{*}$ & -1.45 & $-3.76 * *$ & $-3.31 * *$ & $-3.08 * *$ & $19.16^{* *}$ & $22.10 * *$ & $33.20 * *$ & $71.43 * *$ & $53.19 * *$ & $71.43 * *$ \\
\hline 32 & HB $30 \times$ HB 9-15 & 0.00 & 1.43 & $2.90 *$ & -0.24 & 0.00 & 0.24 & $7.92 * *$ & $9.88 * *$ & $19.86 * *$ & $31.25 * *$ & $34.04 * *$ & $50.00 * *$ \\
\hline 33 & HB $30 \times$ HB 9-16 & 1.45 & 0.00 & 1.45 & 1.20 & -0.47 & -0.24 & $8.97 * *$ & $6.63 * *$ & $16.32 * *$ & $-13.33 *$ & $-17.02 * *$ & -7.14 \\
\hline 34 & HB 50 x DFB $14-1$ & -1.39 & 1.43 & $2.90 *$ & -0.47 & 0.00 & 0.24 & $10.16 * *$ & $19.11 * *$ & $29.93 * *$ & $28.57 * *$ & $14.89 * *$ & $28.57 * *$ \\
\hline 35 & HB 50 x HB 9-15 & -0.47 & 0.95 & 2.42 & -0.24 & 0.00 & 0.24 & $9.68 * *$ & $18.59 * *$ & $29.37 * *$ & $25.00 * *$ & $27.66 * *$ & $42.86 * *$ \\
\hline 36 & HB $50 \times$ HB 9-16 & $3.86 * *$ & 2.38 & $3.86^{* *}$ & $2.40 * *$ & 0.71 & 0.95 & 0.42 & $8.58 * *$ & $18.44 * *$ & $26.67 * *$ & $21.28 * *$ & $35.71 * *$ \\
\hline 37 & IC 598958 x DFB 14-1 & 0.00 & $2.86^{*}$ & $4.35^{* *}$ & 1.18 & $1.65 *$ & $1.90 *$ & $-15.61 * *$ & $-13.53 * *$ & $-5.67 * *$ & 7.14 & -4.26 & 7.14 \\
\hline 38 & IC $598958 \times$ HB 9-15 & 1.41 & $2.86^{*}$ & $4.35^{* *}$ & -0.94 & -0.71 & -0.47 & $-9.26 * *$ & $-7.61 * *$ & 0.79 & $12.50 *$ & $14.89 * *$ & $28.57 * *$ \\
\hline 39 & IC $598958 \times$ HB 9-16 & -0.94 & 0.00 & 1.45 & -0.47 & -0.71 & -0.47 & $-10.07 * *$ & $-8.84 * *$ & -0.56 & -6.67 & $-10.64 *$ & 0.00 \\
\hline 40 & IC 374731 x DFB 14-1 & $-6.02 * *$ & $-3.33 *$ & -1.93 & $-2.59 * *$ & $-2.13 * *$ & $-1.90 *$ & $-11.38 * *$ & $-5.86 * *$ & 2.70 & $31.43 * *$ & $46.81 * *$ & $64.29 * *$ \\
\hline 41 & IC 374731 x HB 9-15 & $-4.23 * *$ & $-2.86 *$ & -1.45 & $-2.36 * *$ & $-2.13 * *$ & $-1.90 *$ & $-8.07 * *$ & -2.34 & $6.53 * *$ & $20.00 * *$ & $34.04 * *$ & $50.00 * *$ \\
\hline 42 & IC $374731 \times$ HB 9-16 & $-2.82 *$ & -1.43 & 0.00 & -1.19 & $-1.89 *$ & $-1.66 *$ & $-15.48 * *$ & $-10.21 * *$ & -2.05 & 8.57 & $21.28 * *$ & $35.71 * *$ \\
\hline 43 & EC 10845 x DFB $14-1$ & -1.39 & 1.43 & $2.90 *$ & -0.24 & 0.24 & 0.47 & -2.78 & 2.34 & $11.64 * *$ & $25.00 * *$ & $27.66 * *$ & $42.86 * *$ \\
\hline 44 & EC 10845 x HB 9-15 & $-3.76 * *$ & -2.38 & -0.97 & -0.94 & -0.71 & -0.47 & $-3.52 *$ & 1.56 & $10.78 * *$ & -6.25 & -4.26 & 7.14 \\
\hline 45 & EC $10845 \times$ HB 9-16 & $2.86^{*}$ & $2.86 *$ & $4.35^{* *}$ & $2.39 * *$ & 1.18 & 1.42 & $-11.67 * *$ & $-7.02 * *$ & 1.43 & $31.25 * *$ & $34.04 * *$ & $50.00 * *$ \\
\hline \multicolumn{2}{|c|}{$\begin{array}{l}\text { No. of crosses with significant } \\
\text { positive heterosis }\end{array}$} & 5 & 6 & 20 & 4 & 1 & 1 & 15 & 19 & 30 & 18 & 25 & 35 \\
\hline $\begin{array}{l}\text { No. } 0 \\
\text { nega }\end{array}$ & $\begin{array}{l}\text { osses with significant } \\
\text { heterosis }\end{array}$ & 18 & 8 & 3 & 15 & 14 & 13 & 21 & 16 & 7 & 12 & 7 & 0 \\
\hline Rang & Lowest & -9.26 & -6.67 & -5.31 & -3.76 & -3.31 & -3.08 & -19.80 & -16.00 & -8.37 & -33.33 & -17.02 & -7.14 \\
\hline heter & Highest & 3.86 & 2.86 & 4.35 & 2.40 & 1.65 & 1.90 & 29.96 & 27.17 & 38.73 & 71.43 & 53.19 & 71.43 \\
\hline
\end{tabular}

*, ** Significant at 5 and 1 per cent probability levels, respectively 
Contd..... Table. 2

\begin{tabular}{|c|c|c|c|c|c|c|c|c|c|c|c|c|c|}
\hline \multirow{2}{*}{$\begin{array}{l}\text { Sl. } \\
\text { No. }\end{array}$} & \multirow[t]{2}{*}{ Crosses } & \multicolumn{3}{|c|}{ Number of pods per plant } & \multicolumn{3}{|c|}{ Pod length (cm) } & \multicolumn{3}{|c|}{ Number of seeds per pod } & \multicolumn{3}{|c|}{ Biological yield per plant (g) } \\
\hline & & BP & $\mathrm{SV}_{1}$ & $\mathrm{SV}_{2}$ & BP & $\mathrm{SV}_{1}$ & $\mathrm{SV}_{2}$ & $\mathbf{B P}$ & $\mathrm{SV}_{1}$ & $\mathrm{SV}_{2}$ & BP & $\mathrm{SV}_{1}$ & $\mathrm{SV}_{2}$ \\
\hline 1 & EC 243626 x DFB 14-1 & $-20.33 * *$ & $-30.29 * *$ & $-24.48 * *$ & -5.83 & $20.95 * *$ & $23.31 * *$ & -4.17 & 2.22 & -7.35 & $-14.55^{* *}$ & $-15.78 * *$ & $-15.08 * *$ \\
\hline 2 & EC $243626 \times$ HB 9-15 & $23.56 * *$ & 3.37 & 11.98 & $12.47 * *$ & $26.68 * *$ & $29.15 * *$ & -2.08 & 4.44 & -5.34 & 5.20 & 3.69 & 4.55 \\
\hline 3 & EC $243626 \times$ HB 9-16 & $58.89 * *$ & $37.50 * *$ & $48.96^{* *}$ & $28.70 * *$ & $52.45 * *$ & $55.42 * *$ & 3.44 & $10.33^{*}$ & 0.00 & $35.97 * *$ & $34.02 * *$ & $35.12 * *$ \\
\hline 4 & EC 329706 x DFB 14-1 & $22.51 * *$ & $12.50^{*}$ & $21.88 * *$ & $-34.66 * *$ & $-10.97 * *$ & -9.24 & 0.00 & 0.00 & $-9.37 *$ & -5.14 & -1.64 & -0.83 \\
\hline 5 & EC $329706 \times$ HB 9-15 & $32.98 * *$ & $22.12 * *$ & $32.29 * *$ & $-32.28 * *$ & -7.73 & -5.93 & 1.44 & 1.44 & -8.06 & -2.96 & 0.61 & 1.45 \\
\hline 6 & EC $329706 \times$ HB 9-16 & $38.22 * *$ & $26.92 * *$ & $37.50 * *$ & $-36.85 * *$ & $-13.97 * *$ & $-12.29 *$ & -5.89 & -5.89 & $-14.70 * *$ & $30.43 * *$ & $35.25 * *$ & $36.36 * *$ \\
\hline 7 & EC $301470 \times$ DFB 14-1 & $35.71 * *$ & $18.75 * *$ & $28.65 * *$ & $-19.84 * *$ & $24.94 * *$ & $27.37 * *$ & -2.65 & $10.33^{*}$ & 0.00 & $12.94 * *$ & $18.03 * *$ & $19.01 * *$ \\
\hline 8 & EC $301470 \times$ HB 9-15 & $64.41 * *$ & $39.90 * *$ & $51.56 * *$ & $-23.36 * *$ & $19.45 * *$ & $21.78 * *$ & -6.57 & 5.89 & -4.03 & $15.88 * *$ & $21.11 * *$ & $22.11 * *$ \\
\hline 9 & EC 301470 x HB 9-16 & $20.56^{* *}$ & 4.33 & 13.02 & $-20.69 * *$ & $23.61 * *$ & $26.02 * *$ & -6.57 & 5.89 & -4.03 & -5.88 & -1.64 & -0.83 \\
\hline 10 & EC $454751 \times$ DFB $14-1$ & $38.83 * *$ & $37.50 * *$ & $48.96 * *$ & -3.69 & $23.69 * *$ & $26.10 * *$ & -8.33 & -2.22 & $-11.38 * *$ & $29.18 * *$ & $29.71 * *$ & $30.79 * *$ \\
\hline 11 & EC $454751 \times$ HB 9-15 & $26.70 * *$ & $25.48 * *$ & $35.94 * *$ & -4.62 & $15.05 * *$ & $17.29 * *$ & $-11.77 * *$ & -5.89 & $-14.70 * *$ & $24.29 * *$ & $24.80 * *$ & $25.83 * *$ \\
\hline 12 & EC $454751 \times$ HB 9-16 & $52.43 * *$ & $50.96 * *$ & $63.54 * *$ & -4.27 & $15.46 * *$ & $17.71 * *$ & -3.13 & 3.33 & -6.34 & $23.88 * *$ & $24.39 * *$ & $25.41 * *$ \\
\hline 13 & EC $263620 \times$ DFB 14-1 & -13.02 & $-19.71 * *$ & -13.02 & $12.82 * *$ & $44.89 * *$ & $47.71 * *$ & $10.33^{*}$ & $10.33^{*}$ & 0.00 & $-19.96 * *$ & $-17.83 * *$ & $-17.15^{* *}$ \\
\hline 14 & EC $263620 x$ HB 9-15 & -5.21 & $-12.50^{*}$ & -5.21 & 6.53 & $35.66 * *$ & $38.31 * *$ & 0.00 & 0.00 & $-9.37 *$ & -9.38 & -6.97 & -6.20 \\
\hline 15 & EC $263620 \times$ HB 9-16 & -2.60 & -10.10 & -2.60 & $30.87 * *$ & $66.67 * *$ & $69.92 * *$ & $33.33 * *$ & $33.33 * *$ & $20.85^{* *}$ & 4.99 & 7.79 & 8.68 \\
\hline 16 & EC 5873 x DFB 14-1 & $-16.48 *$ & $-26.92 * *$ & $-20.83 * *$ & $-11.46^{* *}$ & $13.72 * *$ & $15.93 * *$ & 0.00 & 0.00 & $-9.37 *$ & $-22.97 * *$ & $-22.34 * *$ & $-21.69 * *$ \\
\hline 17 & EC5873 x HB 9-15 & 9.88 & -9.13 & -1.56 & 1.70 & $24.27 * *$ & $26.69 * *$ & -1.11 & -1.11 & $-10.37 *$ & -5.69 & -4.92 & -4.13 \\
\hline 18 & EC $5873 \times$ HB 9-16 & 3.33 & -10.58 & -3.13 & $-13.61 * *$ & 5.57 & 7.63 & 0.00 & 0.00 & $-9.37 *$ & -5.28 & -4.51 & -3.72 \\
\hline 19 & EC 10719 x DFB 14-1 & 4.40 & -8.65 & -1.04 & $-20.70 * *$ & $31.17 * *$ & $33.73 * *$ & $-15.79 * *$ & 6.67 & -3.32 & $-16.94 * *$ & -6.56 & -5.79 \\
\hline 20 & EC $10719 \times$ HB 9-15 & 5.88 & $-13.46^{*}$ & -6.25 & $-21.66 * *$ & $29.59 * *$ & $32.12 * *$ & $-10.53 * *$ & $13.33 * *$ & 2.72 & $-17.67 * *$ & -7.38 & -6.61 \\
\hline 21 & EC 10719 x HB 9-16 & 11.11 & -3.85 & 4.17 & $-31.21 * *$ & $13.80 * *$ & $16.02 * *$ & $-15.79 * *$ & 6.67 & -3.32 & $-20.40 * *$ & $-10.45^{*}$ & -9.71 \\
\hline 22 & EC 329627 x DFB 14-1 & 10.44 & -3.37 & 4.69 & $-29.44 * *$ & 3.82 & 5.85 & $-25.00 * *$ & 0.00 & $-9.37 *$ & $-16.89 * *$ & $-12.30 *$ & $-11.57 *$ \\
\hline 23 & EC 329627 x HB 9-15 & $54.11 * *$ & 8.17 & $17.19^{*}$ & $-14.52 * *$ & $25.77 * *$ & $28.22 * *$ & $-14.42 * *$ & $14.11 * *$ & 3.42 & $10.87 *$ & $17.01 * *$ & $17.98 * *$ \\
\hline 24 & EC $329627 \times$ HB 9-16 & 5.00 & -9.13 & -1.56 & $-23.05 * *$ & $13.22 *$ & $15.42 * *$ & $-17.25 * *$ & $10.33 *$ & 0.00 & $-21.36^{* *}$ & $-17.01 * *$ & $-16.32 * *$ \\
\hline 25 & EC 25085 x DFB $14-1$ & $-13.19 *$ & -1.92 & 6.25 & $-13.46^{* *}$ & $11.14 *$ & $13.31 *$ & $12.84 * *$ & $10.33 *$ & 0.00 & -2.16 & 2.05 & 2.89 \\
\hline 26 & EC $25085 \times$ HB 9-15 & $-29.36 * *$ & $-20.19 * *$ & $-13.54 *$ & $-9.06 *$ & 8.48 & $10.59 *$ & 6.26 & 0.00 & $-9.37 *$ & $-11.79 *$ & -7.99 & -7.23 \\
\hline 27 & EC $25085 \times$ HB 9-16 & $-17.02 * *$ & -6.25 & 1.56 & -5.92 & $12.22 *$ & $14.41 * *$ & 6.67 & 6.67 & -3.32 & -7.66 & -3.69 & -2.89 \\
\hline 28 & HB 10 x DFB 14-1 & $56.45 * *$ & $39.90 * *$ & $51.56^{* *}$ & -6.47 & $20.12 * *$ & $22.46 * *$ & 3.67 & 3.67 & -6.04 & $37.15 * *$ & $20.29 * *$ & $21.28 * *$ \\
\hline 29 & HB $10 \times$ HB 9-15 & $41.94 * *$ & $26.92 * *$ & $37.50 * *$ & $26.72 * *$ & $39.57 * *$ & $42.29 * *$ & $10.33^{*}$ & $10.33 *$ & 0.00 & $47.43 * *$ & $29.30 * *$ & $30.37 * *$ \\
\hline 30 & HB $10 \times$ HB 9-16 & $41.94 * *$ & $26.92 * *$ & $37.50 * *$ & $-9.61 *$ & 7.07 & 9.15 & 7.33 & 7.33 & -2.72 & $52.80 * *$ & $34.02 * *$ & $35.12 * *$ \\
\hline 31 & HB $30 \times$ DFB $14-1$ & $26.92 * *$ & 11.06 & $20.31 * *$ & $-28.84 * *$ & -2.58 & -0.68 & -1.39 & 2.22 & -7.35 & $40.58 * *$ & $19.26 * *$ & $20.25 * *$ \\
\hline 32 & HB $30 \times$ HB 9-15 & $75.68 * *$ & $25.00 * *$ & $35.42 * *$ & 0.91 & $38.15 * *$ & $40.85 * *$ & $10.72 *$ & $14.78 * *$ & 4.03 & $66.75 * *$ & $30.53 * *$ & $31.61 * *$ \\
\hline 33 & HB 30 x HB 9-16 & -13.33 & $-25.00 * *$ & $-18.75 * *$ & $-24.59 * *$ & 3.24 & 5.25 & -3.54 & 0.00 & $-9.37 *$ & 0.26 & $-21.31 * *$ & $-20.66 * *$ \\
\hline 34 & HB 50 x DFB $14-1$ & $33.83 * *$ & $29.33 * *$ & $40.10 * *$ & $-32.82 * *$ & $-13.72 * *$ & $-12.03^{*}$ & $-15.28 * *$ & -0.22 & $-9.57 *$ & $11.75 * *$ & $22.75 * *$ & $23.76 * *$ \\
\hline 35 & HB $50 \times$ HB 9-15 & $53.73 * *$ & $48.56 * *$ & $60.94 * *$ & $-21.48 * *$ & -0.67 & 1.27 & $-15.57 * *$ & -0.56 & $-9.87 *$ & $18.84 * *$ & $30.53 * *$ & $31.61 * *$ \\
\hline
\end{tabular}




\begin{tabular}{|c|c|c|c|c|c|c|c|c|c|c|c|c|c|c|}
\hline 36 & \multicolumn{2}{|c|}{ HB $50 \times$ HB 9-16 } & $17.91 * *$ & $13.94 *$ & $23.44 * *$ & $21.48 * *$ & $53.70 * *$ & $56.69 * *$ & 4.43 & $23.00 * *$ & $11.48 * *$ & 1.49 & $11.48 *$ & $12.40 *$ \\
\hline 37 & \multicolumn{2}{|c|}{ IC $598958 \times$ DFB $14-1$} & $-36.20 * *$ & $-32.21 * *$ & $-26.56 * *$ & $-29.72 * *$ & -5.24 & -3.39 & -5.89 & -5.89 & $-14.70 * *$ & $-39.32 * *$ & $-30.74 * *$ & $-30.17 * *$ \\
\hline 38 & \multicolumn{2}{|c|}{ IC $598958 \times$ HB 9-15 } & 4.52 & 11.06 & $20.31 * *$ & $-20.90 * *$ & 6.65 & 8.73 & 2.22 & 2.22 & -7.35 & -6.46 & 6.76 & 7.64 \\
\hline 39 & \multicolumn{2}{|c|}{ IC $598958 \times$ HB 9-16 } & $-17.19 * *$ & -12.02 & -4.69 & $21.02 * *$ & $63.18 * *$ & $66.36 * *$ & $33.33 * *$ & $33.33 * *$ & $20.85 * *$ & -7.00 & 6.15 & 7.02 \\
\hline 40 & \multicolumn{2}{|c|}{ IC $374731 \times$ DFB $14-1$} & $-16.11 * *$ & $-14.90 *$ & -7.81 & -0.97 & $36.24 * *$ & $38.90 * *$ & $18.56^{* *}$ & $18.56^{* *}$ & 7.45 & $-10.68 *$ & -0.61 & 0.21 \\
\hline 41 & \multicolumn{2}{|c|}{ IC $374731 \times$ HB 9-15 } & 10.90 & $12.50 *$ & $21.88 * *$ & $-24.05 * *$ & 4.49 & 6.53 & 8.89 & 8.89 & -1.31 & 1.84 & $13.32 * *$ & $14.26 * *$ \\
\hline 42 & \multicolumn{2}{|c|}{ IC $374731 \times$ HB 9-16 } & $17.06 * *$ & $18.75 * *$ & $28.65 * *$ & $-38.67 * *$ & $-15.63 * *$ & $-13.98 * *$ & -5.89 & -5.89 & $-14.70 * *$ & 5.34 & $17.21 * *$ & $18.18 * *$ \\
\hline 43 & \multicolumn{2}{|c|}{ EC $10845 \times$ DFB $14-1$} & $-12.50 *$ & -9.13 & -1.56 & -4.53 & $22.61 * *$ & $25.00 * *$ & -0.73 & 5.89 & -4.03 & -5.45 & -0.41 & 0.41 \\
\hline 44 & \multicolumn{2}{|c|}{ EC $10845 \times$ HB $9-15$} & $-16.67 * *$ & $-13.46^{*}$ & -6.25 & $-24.92 * *$ & -4.82 & -2.97 & -6.25 & 0.00 & $-9.37 *$ & -5.06 & 0.00 & 0.83 \\
\hline 45 & \multicolumn{2}{|c|}{ EC 10845 x HB 9-16 } & 8.33 & $12.50 *$ & $21.88 * *$ & -7.61 & $17.12 * *$ & $19.41 * *$ & -4.17 & 2.22 & -7.35 & 2.14 & 7.58 & 8.47 \\
\hline \multicolumn{3}{|c|}{$\begin{array}{l}\text { No. of crosses with significant } \\
\text { positive heterosis }\end{array}$} & 21 & 19 & 22 & 7 & 29 & 30 & 7 & 13 & 3 & 15 & 18 & 18 \\
\hline \multicolumn{3}{|c|}{$\begin{array}{l}\text { No. of crosses with significant } \\
\text { negative heterosis }\end{array}$} & 10 & 10 & 5 & 26 & 4 & 3 & 9 & 0 & 16 & 11 & 8 & 7 \\
\hline \multirow{2}{*}{\multicolumn{2}{|c|}{$\begin{array}{l}\text { Range of } \\
\text { heterosis }\end{array}$}} & Lowest & -36.20 & -32.21 & -26.56 & -38.67 & -15.63 & -13.98 & -25.00 & -5.89 & -14.70 & -39.32 & -30.74 & -30.17 \\
\hline & & Highest & 75.68 & 50.96 & 63.54 & 30.87 & 66.67 & 69.92 & 33.33 & 33.33 & 20.85 & 66.75 & 35.25 & 36.36 \\
\hline
\end{tabular}

*, ** Significant at 5 and 1 per cent probability levels, respectively

\section{Contd..... Table.2}

\begin{tabular}{|c|c|c|c|c|c|c|c|c|c|c|c|c|c|}
\hline \multirow[t]{2}{*}{ S. No. } & \multirow[t]{2}{*}{ Crosses } & \multicolumn{3}{|c|}{ Harvest index (\%) } & \multicolumn{3}{|c|}{ 100-seed weight (g) } & \multicolumn{3}{|c|}{ Protein content (\%) } & \multicolumn{3}{|c|}{ Grain yield per plant (g) } \\
\hline & & BP & $\mathrm{SV}_{1}$ & $\mathbf{S V}_{2}$ & BP & $\mathrm{SV}_{1}$ & $\mathbf{S V}_{2}$ & BP & $\mathrm{SV}_{1}$ & $\mathrm{SV}_{2}$ & BP & $\mathrm{SV}_{1}$ & $\mathbf{S V}_{2}$ \\
\hline 1 & EC 243626 x DFB 14-1 & $-9.49^{*}$ & $-16.92 * *$ & $-15.16^{* *}$ & -1.37 & $-2.74 * *$ & $3.53^{* *}$ & $31.39 * *$ & $13.31^{* *}$ & $10.88^{* *}$ & $-21.64 *$ & $-30.02 * *$ & $-28.03^{* *}$ \\
\hline 2 & EC 243626 x HB 9-15 & $16.56^{* *}$ & 5.75 & $7.98^{*}$ & $-4.13 * *$ & -0.48 & $5.93 * *$ & $-8.07 * *$ & $-10.95 * *$ & $-12.87^{* *}$ & $22.75^{*}$ & 9.62 & 12.74 \\
\hline 3 & EC $243626 \times$ HB 9-16 & $20.39 * *$ & $9.23^{*}$ & $11.53^{* *}$ & $-2.73^{* *}$ & $-4.08 * *$ & 2.10 & $-7.20 * *$ & $-11.61 * *$ & $-13.50 * *$ & $63.82^{* * *}$ & $46.30^{* *}$ & $50.46^{* *}$ \\
\hline 4 & EC 329706 x DFB $14-$ & $9.60^{*}$ & 0.61 & 2.73 & $-10.97^{* *}$ & $-10.55 * *$ & $-4.79 * *$ & $-19.53^{* *}$ & $-9.80 * *$ & $-11.74 * *$ & 4.84 & -1.04 & 1.77 \\
\hline 5 & EC 329706 x HB 9-15 & $14.64 * *$ & 4.26 & 6.46 & $-19.30 * *$ & $-16.22 * *$ & $-10.83 * *$ & $-12.66 * *$ & -2.10 & $-4.20 * *$ & 11.06 & 4.83 & 7.81 \\
\hline 6 & EC 329706 x HB 9-16 & 5.47 & -4.08 & -2.05 & $7.89 * *$ & $8.40 * *$ & $15.38^{* *}$ & 0.22 & $12.34 * *$ & $9.93 * *$ & $37.37 * *$ & $29.66^{* *}$ & $33.34 * *$ \\
\hline 7 & EC 301470 x DFB 14-1 & $9.24 *$ & $9.82 * *$ & $12.14 * *$ & $-10.98^{* *}$ & $-2.87 * *$ & $3.39 * *$ & $-5.44 * *$ & $-18.27 * *$ & $-20.02 * *$ & $23.38^{* * *}$ & $29.54 * *$ & $33.23 * *$ \\
\hline 8 & EC 301470 x HB 9-15 & $8.55^{*}$ & $9.12 *$ & $11.43^{* *}$ & $-17.12 * *$ & $-9.57 * *$ & $-3.74 * *$ & $17.97^{* *}$ & $14.27 * *$ & $11.82 * *$ & $25.91 * *$ & $32.20 * *$ & $35.95^{* *}$ \\
\hline 9 & EC $301470 \times$ HB 9-16 & $8.93^{*}$ & $9.51 * *$ & $11.82^{* *}$ & $-8.93 * *$ & -0.64 & $5.76^{* * *}$ & $8.86^{* *}$ & $3.69^{*}$ & 1.47 & 2.61 & 7.73 & 10.80 \\
\hline 10 & EC $454751 \times$ DFB $14-1$ & $10.78^{* *}$ & 3.99 & 6.18 & $7.52 * *$ & 1.00 & $7.51^{* *}$ & $16.77^{* *}$ & $12.23^{* *}$ & $9.82 * *$ & $43.09^{* *}$ & $34.93^{* *}$ & $38.77 * *$ \\
\hline 11 & EC 454751 x HB 9-15 & 3.06 & -3.25 & -1.21 & $-2.61 * *$ & 1.09 & $7.61 * *$ & $-9.88^{* *}$ & $-12.70^{* *}$ & $-14.58 * *$ & $28.04 * *$ & $20.74 * *$ & $24.17 * *$ \\
\hline 12 & EC $454751 \times$ HB 9-16 & $13.59 * *$ & 6.63 & $8.88^{*}$ & $-4.27 * *$ & $-10.07 * *$ & $-4.28 * *$ & $-8.61 * *$ & $-12.16 * *$ & $-14.05 * *$ & $40.72 * *$ & $32.70 * *$ & $36.48 * *$ \\
\hline 13 & EC 263620 x DFB $14-1$ & $12.08^{* *}$ & 6.23 & $8.47^{*}$ & $-8.55^{* *}$ & $-4.77 * *$ & 1.37 & 1.14 & $7.07 * *$ & $4.77 * *$ & -10.11 & -12.67 & -10.19 \\
\hline 14 & EC 263620 x HB 9-15 & 5.61 & 0.10 & 2.21 & 0.51 & $4.67 * *$ & $11.41 * *$ & $-6.26 * *$ & -0.76 & $-2.89 *$ & -4.01 & -6.74 & -4.09 \\
\hline 15 & EC $263620 \times$ HB 9-16 & $19.34 * *$ & $13.11^{* *}$ & $15.50 * *$ & $-4.79 * *$ & -0.86 & $5.53^{* *}$ & $-10.41 * *$ & $-5.16^{* *}$ & $-7.20 * *$ & $25.62 * *$ & $22.04 * *$ & $25.51^{* *}$ \\
\hline 16 & EC 5873 x DFB 14-1 & -0.56 & $-8.72 *$ & -6.79 & 0.69 & $-4.21 * *$ & 1.96 & $-17.08 * *$ & $-18.63 * *$ & $-20.38 * *$ & -11.29 & $-29.03 * *$ & $-27.02 * *$ \\
\hline
\end{tabular}


Int.J.Curr.Microbiol.App.Sci (2019) 8(6): 662-677

\begin{tabular}{|c|c|c|c|c|c|c|c|c|c|c|c|c|c|}
\hline 17 & EC5873 x HB 9-15 & 1.94 & $-9.26^{*}$ & $-7.35^{*}$ & $-10.06 * *$ & $-6.63 * *$ & -0.62 & $15.37 * *$ & $13.20^{* *}$ & $10.77^{* *}$ & 7.94 & -13.66 & -11.20 \\
\hline 18 & EC $5873 \times$ HB 9-16 & $8.52 *$ & -6.11 & -4.13 & 1.60 & $-3.35 * *$ & $2.88 * *$ & $7.05^{* *}$ & $5.04 * *$ & $2.78^{*}$ & 12.35 & -10.13 & -7.57 \\
\hline 19 & EC 10719 x DFB $14-1$ & 1.94 & 3.48 & 5.67 & $-11.39 * *$ & $-2.56^{*}$ & $3.72 * *$ & $10.57 * *$ & $3.08 *$ & 0.87 & $-15.20^{*}$ & -3.22 & -0.46 \\
\hline 20 & EC 10719 x HB 9-15 & 1.91 & 3.45 & 5.64 & $-14.03 * *$ & $-5.46 * *$ & 0.63 & -1.23 & $-4.33 * *$ & $-6.39 * *$ & $-16.07^{*}$ & -4.20 & -1.48 \\
\hline 21 & EC $10719 \times$ HB 9-16 & 1.19 & 2.72 & 4.89 & $-20.62 * *$ & $-12.71 * *$ & $-7.08 * *$ & $-8.47 * *$ & $-12.81 * *$ & $-14.69^{* *}$ & $-19.33^{* *}$ & -7.93 & -5.31 \\
\hline 22 & EC 329627 x DFB 14-1 & 6.23 & -2.49 & -0.43 & $-20.94 * *$ & $-13.57 * *$ & $-8.00 * *$ & $30.46^{* *}$ & $12.51^{* *}$ & $10.09 * *$ & -11.32 & -14.45 & -12.01 \\
\hline 23 & EC 329627 x HB 9-15 & $13.67 * *$ & 3.97 & 6.16 & $-9.27 * *$ & -0.82 & $5.57 * *$ & $-8.54 * *$ & $-11.41 * *$ & $-13.31 * *$ & $26.00^{* *}$ & $21.56^{* *}$ & $25.01 * *$ \\
\hline 24 & EC $329627 \times$ HB 9-16 & $17.54 * *$ & $7.51 *$ & $9.78 * *$ & $-20.24 * *$ & $-12.81 * *$ & $-7.19 * *$ & $-7.87 * *$ & $-12.24 * *$ & $-14.13^{* *}$ & -7.58 & -10.84 & -8.30 \\
\hline 25 & EC 25085 x DFB 14-1 & 1.76 & -3.13 & -1.09 & $-4.38 * *$ & $-10.72 * *$ & $-4.97 * *$ & $-16.94 * *$ & $-8.70^{* *}$ & $-10.66^{* *}$ & -0.43 & -1.10 & 1.71 \\
\hline 26 & EC $25085 \times$ ×B 9-15 & -6.58 & $-11.07 * *$ & $-9.19 *$ & $-2.31 *$ & 1.41 & $7.94 * *$ & $-10.79 * *$ & -1.94 & $-4.05^{* *}$ & $-17.59 *$ & $-18.14^{*}$ & -15.82 \\
\hline 27 & EC $25085 \times$ HB 9-16 & $10.36^{* * *}$ & 5.05 & $7.27 *$ & $7.18 * *$ & 0.07 & $6.51 * *$ & 1.96 & $12.06^{* *}$ & $9.66^{* *}$ & 1.99 & 1.30 & 4.18 \\
\hline 28 & HB 10 x DFB $14-1$ & 1.09 & -0.06 & 2.05 & $-11.29 * *$ & $-14.84 * *$ & $-9.35 * *$ & $16.87^{* * *}$ & $3.89^{* *}$ & 1.66 & $38.54 * *$ & $20.20^{*}$ & $23.62 * *$ \\
\hline 29 & HB $10 \times$ HB 9-15 & $9.51^{*}$ & $8.27 *$ & $10.56^{* *}$ & $-2.56^{* *}$ & 1.15 & $7.67 * *$ & -0.96 & $-4.07 * *$ & $-6.13^{* *}$ & $61.30^{* *}$ & $39.95^{* *}$ & $43.93^{* *}$ \\
\hline 30 & HB 10 x HB 9-16 & 5.92 & 4.72 & 6.93 & $9.75 * *$ & $5.36 * *$ & $12.15^{* *}$ & $-8.25 * *$ & $-12.61 * *$ & $-14.48^{* *}$ & $61.69 * *$ & $40.29 * *$ & $44.28 * *$ \\
\hline 31 & HB $30 \times$ DFB $14-1$ & $-11.29 * *$ & $-8.97 *$ & -7.05 & -1.44 & $-6.72 * *$ & -0.71 & $-18.06 * *$ & $-9.44 * *$ & $-11.38^{* *}$ & $39.49 * *$ & 8.63 & 11.72 \\
\hline 32 & HB $30 \times$ HB 9-15 & $8.39 *$ & $11.23 * *$ & $13.58^{* *}$ & -1.02 & $2.75^{* *}$ & $9.37 * *$ & $-11.29 * *$ & -1.96 & $-4.06^{* *}$ & $100.74 * *$ & $45.12^{* *}$ & $49.25 * *$ \\
\hline 33 & HB $30 \times$ HB 9-16 & $-12.45^{* *}$ & $-10.15^{* * *}$ & $-8.26^{*}$ & $-4.07 * *$ & $-9.21 * *$ & $-3.36^{* *}$ & 0.45 & $11.02 * *$ & $8.64 * *$ & -2.07 & $-29.20 * *$ & $-27.19 * *$ \\
\hline 34 & HB 50 x DFB 14-1 & -2.32 & 2.33 & 4.49 & $-5.67 * *$ & $-5.67 * *$ & 0.40 & $23.84 * *$ & $8.04 * *$ & $5.72 * *$ & 9.20 & $25.56^{* *}$ & $29.14 * *$ \\
\hline 35 & HB 50 x HB 9-15 & 3.31 & $8.22 *$ & $10.51^{* *}$ & $-9.50 * *$ & $-6.05 * *$ & 0.00 & 2.71 & -0.51 & -2.65 & $22.87^{* *}$ & $41.28^{* *}$ & $45.30 * *$ \\
\hline 36 & HB 50 x HB 9-16 & $11.26^{* *}$ & $16.56^{* *}$ & $19.02 * *$ & $-4.21 * *$ & $-4.21 * *$ & 1.96 & -0.63 & $-5.34 * *$ & $-7.38^{* *}$ & 13.01 & $29.94 * *$ & $33.63 * *$ \\
\hline 37 & IC 598958 x DFB $14-1$ & 2.07 & -6.30 & -4.33 & $2.87 * *$ & 1.34 & $7.87 * *$ & $3.36^{*}$ & $7.48^{* *}$ & $5.18^{* *}$ & $-35.75^{* *}$ & $-35.10 * *$ & $-33.26^{* *}$ \\
\hline 38 & IC $598958 \times$ HB 9-15 & $18.18 * *$ & 5.19 & $7.41 *$ & $-6.35^{* *}$ & $-2.78 * *$ & $3.48 * *$ & $-4.25 * *$ & -0.43 & -2.57 & 11.12 & 12.25 & 15.44 \\
\hline 39 & IC 598958 x HB 9-16 & $24.07 * *$ & $9.55^{* *}$ & $11.86^{* *}$ & $-3.32 * *$ & $-4.76 * *$ & 1.38 & $-8.89 * *$ & $-5.26^{* *}$ & $-7.30^{* *}$ & 15.22 & $16.39^{*}$ & $19.70 *$ \\
\hline 40 & IC $374731 \times$ DFB $14-1$ & -4.97 & -3.11 & -1.07 & $-18.99 * *$ & $-7.80 * *$ & -1.87 & $-20.21 * *$ & $-18.44 * *$ & $-20.19 * *$ & $-15.17 *$ & -3.78 & -1.04 \\
\hline 41 & IC 374731 x HB 9-15 & 1.03 & 3.00 & 5.17 & $-18.36^{* *}$ & $-7.09 * *$ & -1.11 & $12.10^{* * *}$ & $14.59^{* *}$ & $12.13^{* *}$ & 2.86 & $16.68^{*}$ & $19.99 *$ \\
\hline 42 & IC 374731 x HB 9-16 & $-9.37 * *$ & $-7.61 *$ & -5.66 & $-16.23 * *$ & $-4.67 * *$ & 1.47 & 2.00 & $4.26 * *$ & 2.02 & -4.53 & 8.30 & 11.38 \\
\hline 43 & EC 10845 x DFB $14-1$ & $-14.25^{* *}$ & $-10.20^{* * *}$ & $-8.30^{*}$ & $-4.57 * *$ & $-9.04 * *$ & $-3.19 * *$ & $10.17^{* * *}$ & $4.03 * *$ & 1.79 & $-18.75^{* *}$ & -10.47 & -7.92 \\
\hline 44 & EC $10845 \times$ HB 9-15 & $-20.54 * *$ & $-16.79 * *$ & $-15.03 * *$ & $-7.86^{* *}$ & $-4.35 * *$ & 1.81 & -1.36 & $-4.46^{* *}$ & $-6.51 * *$ & $-24.46^{* *}$ & $-16.76^{*}$ & -14.39 \\
\hline 45 & EC $10845 \times$ HB 9-16 & 3.97 & $8.88^{*}$ & $11.17^{* *}$ & $9.51 * *$ & $4.38^{* *}$ & $11.10^{* *}$ & $-8.23 * *$ & $-12.59 * *$ & $-14.47 * *$ & 6.27 & $17.10^{*}$ & $20.43^{*}$ \\
\hline $\begin{array}{l}\text { No. o } \\
\text { positi }\end{array}$ & $\begin{array}{l}\text { osses with significant } \\
\text { leterosis }\end{array}$ & 20 & 12 & 17 & 6 & 5 & 20 & 13 & 18 & 13 & 16 & 19 & 19 \\
\hline $\begin{array}{l}\text { No. o } \\
\text { negat }\end{array}$ & $\begin{array}{l}\text { osses with significant } \\
\text { heterosis }\end{array}$ & 6 & 9 & 6 & 33 & 30 & 11 & 22 & 21 & 25 & 9 & 6 & 4 \\
\hline Rang & \begin{tabular}{|l|l|} 
Lowest \\
\end{tabular} & -20.54 & -16.92 & -15.16 & -20.94 & -16.22 & -10.83 & -20.21 & -18.63 & -20.38 & -35.75 & -35.10 & -33.26 \\
\hline & Highest & 24.07 & 16.56 & 19.02 & 9.75 & 8.40 & 15.38 & 31.39 & 14.59 & 12.13 & 100.74 & 46.30 & 50.46 \\
\hline
\end{tabular}

*, ** Significant at 5 and 1 per cent probability levels, respectively 
On the contrary, there can be a cross with high mean performance but low heterosis in case parental performance is also high. The mean performance being the realized value and the heterotic response being an estimate, the former should be given due consideration while making selection of cross combinations especially when objective is to identify a hybrid for commercial cultivation as in present case.

In conclusion, a wide range of variation in the estimates of heterobeltiosis and standard heterosis in positive and negative direction was observed for grain yield per plant as well as remaining eleven traits. The most desirable crosses showing high mean performance alongwith high and significant heterosis of one or both types for grain yield per plant were EC 243626 x HB 9-16, HB 30 x HB 915, HB 50 x HB 9-15, HB 10 x HB 9-16 and HB $10 \times$ HB 9-15 for faba bean.

The cross, EC 243626 x HB 9-16, showed highest mean performance $(17.28 \mathrm{~g})$, heterobeltiosis $(63.82 \%)$, standard heterosis over $\mathrm{SV}_{1}(46.30 \%)$ and $\mathrm{SV}_{2}(50.46 \%)$ for grain yield per plant while highest yielding parent, HB 50 produced mean grain yield $13.58 \mathrm{~g}$. The other four of the five crosses mentioned above also produced higher grain yield than HB 50. The most desirable crosses showing high mean performance along with high and significant heterosis of one or both types for grain yield per plant merit further testing and evaluation in adaptive trials to find out their feasibility for their recommendation as hybrid cultivars of faba bean.

\section{Acknowledgement}

The first author is grateful to Dr N. P. Singh, Director, ICAR-IIPR, Kanpur for giving the opportunity to pursue Ph.D. degree by granting him study leaves.

\section{References}

Abdalla, M. M. F., M. M. Shafik, M. I. AbdEl-Mohsen, S. R. E. Abo-Hegazy, and Heba A. M. A. Saleh. 2015. Investigation on faba beans, Vicia faba L. Heterosis, inbreeding effects, gca and sca of diallel crosses of ssp. paucijuga and eu-faba. J. Amer. Sci.,11: 1-7.

Abd-El rahman, R. A. M., Ibrahim, M. A., Sabah, M., Attia, M. and ElMarsafawy, T. S. 2012. Combining ability analysis for yield and some agronomic traits in seven faba bean genotypes, Egypt. J. Plant Breed. 16 (3): 135-145.

Alghamdi, S. Salem. 2009. Heterosis and combining ability in a diallel cross of eight faba bean (Vicia faba L.) genotypes. Asian J. Crop Sci., 1: 6676.

Ashrei, A.A.M., Rabi, E.M., Shafei, W. W. M., EL-Garhy, A. M. and AboMostafa R. A. 2014. Performance and analysis of F1and F2 diallel crosses among six parents of faba bean. Egypt. J. Plant Breed., 18 (1):125-137.

Bakhit, B. R. and Abdel-Fatah B. E. 2013. Gene action and molecular markers associated with Orobanche resistance in faba bean (Vicia faba L.) Biotechnology, 12 (1):1-13.

Bishnoi, S. K., Hooda, J. S., Sharma, P. and Kumar, P. 2017. Heterosis and inbreeding depression in yield component traits in faba bean (Vicia faba L.). The Bioscan, 12 (4): 18451850

Bishnoi, S. K., Hooda, J.S., Yadav, I.S. and Panchta, R. 2012. Advances on heterosis and hybrid breeding in faba bean (Vicia faba L.). Forage Res., 38 (2): $65-73$.

Bishnoi, S.K., Hooda, J.S. and Sharma P. 2015. Heterotic responses in yield 
component traits in faba bean (Vicia faba L.). Forage Res., 41 (3): 152159.

El-Banna M. N., Mansour, S. H., Nassar, M. A. A. and Ibrahim, R. A. M. 2014. Genetic analysis of yield, its components and earliness in some faba bean (Vicia faba L.) crosses. Middle East J. Agric. Res., 3 (4): 955961.

El-Hady, M. M., Rizk, A. M. A., Omran, M. $\mathrm{M}$ and Ragheb, S. B. 2007. Genetic behaviour of some Faba bean (Vicia faba L.) genotypes and its crosses. Ann. Agric. Sci., 45: 49-60.

EL-Harty, E.H., Shaaban, M., Omran, M.M. and Ragheb, S.B. 2007. Heterosis and genetic analysis of yield and some characters in faba bean (Vicia faba L.). Minia J. Agric. Res. Develop., 27 (5): 897-913.

Farag, H. I. A. and Afiah, S. A. 2012. Analysis of gene action in diallel crosses among some faba bean (Vicia faba L.) genotypes under Maryout conditions. Ann. Agric. Sci., 57(1): $37-46$

Ibrahim M. Hossam. 2010. Heterosis, combining ability and components of genetic variance in faba bean (Vicia faba L.). JKAU: Met., Env. \& Arid Land Agric. Sci., 21(1): 35-50.

Link, W. 2006. In : International Workshop on Faba bean Breeding and Agronomy, Avila, C. M., Cubero, J. I., Moreno, M. T., Suso, M. J. and Torres, A. M. (eds.). Spain. pp. 35-40.

Maalouf, F. 2011. Faba bean improvement at ICARDA: Constraints and challenges. Grain Legumes, 56: 1314.

Mourad, A.M.I. 2011. Inheritance of some agronomic traits in faba bean (Vicia faba L.). M.Sc. thesis submitted to Assiut University.

Obiadalla-Ali, H. A., Naheif, E. M. M., Ahmed, A. G. and Mohamed, H. Z. E. 2013. Heterosis and nature of gene action for yield and its components in faba bean (Vicia faba L.). J. Plant Breed. Crop Sci., 5 (3): 34-40.

Saad, E. Hussein,Zaghloul and Atef Pasha Sirri .2015. Assessment of heterosis and features of gene activity for yield and its components in faba bean (Vicia faba L.). Int. J. Agril. Sci., 5: 676-681.

Zeinab, E. G. and El-Emam E. A. A. 2013. Genetic behavior of some yield components in four crosses of faba bean. Egypt. J. Plant Breed., 17 (3): 57-66.

Zeinab, E. G. and Helal, A.G. 2014. Diallel analysis and separation of genetic variance components in eight faba bean genotypes, Ann. Agric. Sci., 59 (1):147-154.

\section{How to cite this article:}

Kanhaiya Lal, C.B. Yadav, Shiva Nath and Dwivedi, D.K. 2019. Heterotic Responses for Yield and its Components in Faba Bean (Vicia Faba L.). Int.J.Curr.Microbiol.App.Sci. 8(06): 662-677. doi: https://doi.org/10.20546/ijcmas.2019.806.077 